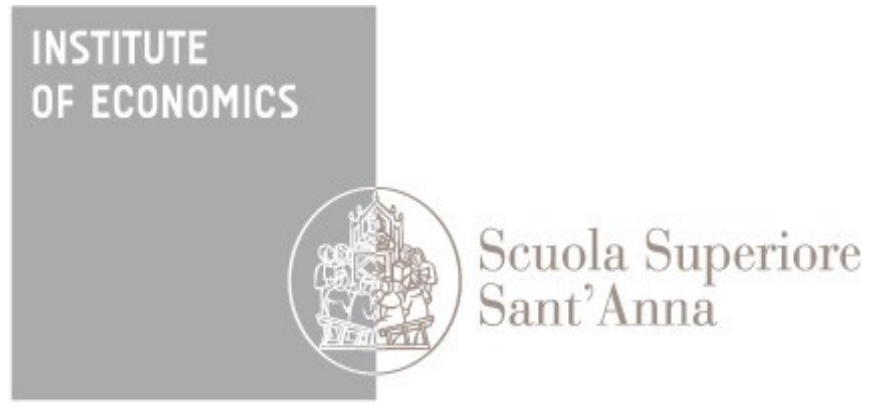

LEM | Laboratory of Economics and Management

Institute of Economics

Scuola Superiore Sant'Anna

Piazza Martiri della Libertà, 33 - 56127 Pisa, Italy ph. +3905088.33 .43$

institute.economics@sssup.it

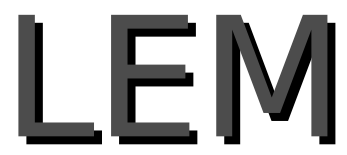

Working Paper Series

\title{
Non-Standard Work and Innovation: Evidence from European industries
}

\author{
Jelena Reljic a,b \\ Armanda Cetrulo ${ }^{b}$ \\ Valeria Cirillo c,b \\ Andrea Coveri ${ }^{d}$
}

a Sapienza University of Rome, Italy.

b Sant'Anna School of Advanced Studies, Pisa, Italy.

"University of Bari "Aldo Moro", Italy.

"University of Urbino "Carlo Bo", Italy. 


\title{
Non-Standard Work and Innovation: Evidence from European industries
}

\author{
Jelena Reljic ${ }^{1,2}$, Armanda Cetrulo ${ }^{2}$, Valeria Cirillo ${ }^{3,2}$, Andrea Coveri ${ }^{4, *}$ \\ ${ }^{1}$ Sapienza University of Rome \\ ${ }^{2}$ Sant'Anna School of Advanced Studies, Pisa \\ ${ }^{3}$ University of Bari "Aldo Moro" \\ ${ }^{4}$ University of Urbino "Carlo Bo" \\ * Corresponding author: andrea.coveri@uniurb.it
}

\begin{abstract}
Following a market-oriented approach, policies aimed at increasing labour flexibility by weakening employment protection institutions should enable firms to efficiently allocate resources, improve their capability to compete on international markets and adjust to economic cycle. This work documents the rise of non-standard (i.e. temporary and part-time) work in five European countries (Germany, France, Italy, the Netherlands and the United Kingdom) over the period 1994-2016 and investigate the nexus between the use of non-standard work and innovation performance using data for 18 manufacturing and 23 service industries. Contrary to the objectives that market-oriented policy recommendations promised to achieve, we show that there is a significantly negative association between the share of workers employed under nonstandard contractual arrangements and the introduction of both product and process innovation. Furthermore, we show that the harmful consequences of the spread of non-standard work on firms' product innovation propensity are more pronounced in high-tech sectors.
\end{abstract}

\section{JEL classification:}

J23; 03; 014

Keywords:

Non-standard work; Knowledge; Product innovation; Process innovation; Industry-level analysis 


\section{Introduction}

The radical paradigm shift in economic policy occurred in the Eighties fostered the introduction of new flexible contractual arrangements with the alleged goal of boosting firms' competitiveness and reducing unemployment rates (OECD 1994). Beyond the impact of these policies on the overall economic performance of European countries (Brancaccio et al. 2018), the institutional changes they entailed led to the fragmentation of the labour market in terms of forms of employment and working time patterns, giving rise to the spread of the so-called 'Non-Standard Work' - hereafter NSW.

Since the 1990s, NSW has accounted for more than half of employment growth (OECD 2015), resulting in a share of employees with non-standard contracts exceeding $30 \%$ in 2018. Despite the need of a comprehensive classification system able to map the huge variety of atypical jobs emerged in recent decades (Cappelli 2013), there is still no consensus on the definition of NSW. ${ }^{1}$ This label is often used to include all types of employment arrangements that differ from the 'standard' (i.e. full-time and permanent) employment relationship. Other terms usually used by researchers to define employment relationships associated with limited access to employment protection and worker rights are 'atypical', 'unstable', 'flexible' and 'precarious' jobs. Indeed, NSW is typically associated with low wages, employment insecurity, poor working conditions and little, if any, career advancement opportunities (Kalleberg 2011).

In this context, several contributions have explored the nexus between the spread of labour flexibility and both productivity and innovation at firm, industry and country level, reporting contrasting findings. Following a market-oriented approach, policies aimed at increasing labour flexibility should enable firms to efficiently allocate resources and adjust to industry and economic cycle, thus soaring the pace of innovation (Bartelsman et al. 2016; Malcomson 1997; Nickell and Layard 1999; Scarpetta and Tressel 2004). This approach has been questioned by a number of contributions having their roots in Classical, Marxian and Schumpeterian Political Economy, which highlighted how - on the contrary - labour flexibility is likely to discourage the introduction of labour-saving technologies and disrupt the accumulation of firm-specific knowledge, ultimately hindering the introduction of innovations and slow down the productivity growth rate.

Along this line, several empirical analyses have been carried out with the aim of empirically investigate the relationship between the deregulation of labour market and technological progress (Cirillo and Ricci 2020; Hoxha and Kleinknecht 2020; Michie and Sheehan 1999, 2003; Vergeer and Kleinknecht 2010). Among industry-level studies, the work by Cetrulo et al. (2019) is worth mentioning. By making use of European industry-level data, the authors assess the existence of a negative relationship between temporary employment and propensity to introduce product innovation. Furthermore, they detect that such relationship is stronger for those industries where tacit firm-specific knowledge plays a leading role in introducing innovations. These industries are more closed to the 'creative accumulation', or the 'Schumpeter mark II' innovation model (Schumpeter 1942). However, the key explanatory variable of their analysis captures just one dimension of NSW (i.e. fixed-term jobs) and the empirical exercise is carried out focusing only on product innovation. It follows that, on the one hand, the analysis provided by Cetrulo et al. (2019) does not allow for a comprehensive

\footnotetext{
${ }^{1}$ Hipp et al. (2015) raised some doubts about the terminology in use, as non-standard work is becoming a 'standard' kind of employment relationship in some countries (e.g. the Netherlands) and especially for some demographic groups (youth, seniors, women and migrants).
} 
assessment of the impact of different forms of NSW on technological progress. On the other hand, their findings suggest that NSW is harmful to the introduction of new products as the latter rely mainly on the accumulation of knowledge but leave open the possibility that nonstandard contractual arrangements might be conducive to the introduction of labour-saving technologies, i.e. process innovations.

This work firstly offers a comprehensive review of the empirical literature about the impact of labour market deregulation on productivity and innovation, allowing for a broad and up-todate assessment of the theoretical debate and extant empirical evidence on the topic. Subsequently, we provide an empirical analysis of the relationship between the evolution of NSW and the propensity to introduce both product and process innovation. To this aim, we build a new variable for tracing the evolution of NSW in five European countries (Germany, France, Italy, the Netherlands and the UK) by aggregating data on employees engaged in fulltime temporary, part-time permanent and part-time temporary contractual arrangements at industry-level. Nonetheless, we examine whether the relationship between non-standard employment arrangements and innovation differs across sectors. In particular, we rely on the Revised Pavitt taxonomy developed by Bogliacino and Pianta $(2010,2016)$ to distinguish between high-tech and low-tech industries according to the nature of knowledge, patterns of innovation and market structure which feature each sector. Notably, to the best of our knowledge, this is the first study that attempts to estimate the impact of the share of NSW on both product and process innovation using industry-level data and explicitly testing the heterogeneous effects of NSW in high- and low-tech industries. Controlling for a wide range of variables that influence the innovation performance of sectors, we find that the share of employees engaged with NSW arrangements is negatively associated with both product and process innovation in European industries. Furthermore, we find that the relationship between non-standard jobs and innovation is not uniform across sectors; notably, we show that the harmful consequences of the spread of NSW on the firms' product innovation propensity are more pronounced in high-tech sectors.

The rest of the paper is organised as follows. In the next section, we define the theoretical framework of our analysis and provide an extensive empirical literature review on the topic. Section 3 introduces the data and offers descriptive evidence on the evolution of NSW in Europe. In Section 4 we present the econometric strategy used in the empirical investigation, while Section 5 discusses the results. Finally, Section 6 provides some concluding remarks.

\section{Setting the framework: background literature and research hypotheses}

\subsection{Non-Standard Work, Innovation and Productivity}

Scholars explored different dimensions of labour flexibility as a type of employment strategy: (i) numerical flexibility, internal (e.g. part-time work) and external (e.g. fixed-term jobs, temporary jobs, temporary agency work); (ii) functional flexibility; and (iii) wage flexibility. Numerical flexibility aims at quantitative adjustment, in terms of a number of employees and working hours, to the firms' changing needs; the latter might be due to, e.g., changes in demand and unexpected workloads, which might induce firms to increase numerical flexibility by hiring non-standard workers in order to reduce labour costs. Functional flexibility encourages within-firm mobility (e.g. across different functions) and relies on employees' ability to adapt to new tasks and the changing nature of jobs. This strategy is often matched with investments 
in training and firms' retention strategies that promote the accumulation of firms' specific knowledge, and in organizational studies functional flexibility is usually associated to HighPerformance Work Practices (Becker and Huselid 1998). Finally, wage flexibility typically refers to a downward adjustment of wages and is closely related to numerical flexibility (Arvanitis 2005; Kleinknecht et al. 2006).

Numerical and functional flexibility as employment strategies can clearly coexist (Atkinson 1984), albeit with heterogeneous effects on firms' performance (Cirillo and Ricci 2020; Kalleberg 2001; Michie and Sheehan 2003). In particular, if there is a broad agreement that functional flexibility enhances production efficiency, there is much less consensus on the impact of numerical flexibility on the pace of product and process innovation. Following the seminal definition of Schumpeter $(1934,66)$, we can broadly describe product innovation as «the introduction of a new good, or a new quality of good» and process innovation as «the introduction of a new method of production (...), a new way of handling a commodity commercially». According to the Community Innovation Survey (provided by Eurostat), the product's novelty can also consist in a significant improvement of its material, technical and functional characteristics. Likewise, process innovation corresponds not only to the introduction of radically new production methods, but it includes also relevant improvements in the production process (in terms of tools, techniques and ICT technology adopted). Given the different nature of product and process innovation, as well as their heterogeneous economic and technological determinants, accounting for this distinction is of major importance to properly investigate the potential impact of NSW on firms' pace of technological change.

The rest of this section defines the theoretical framework of our analysis, discussing the different channels through which labour market flexibility can foster or hamper innovation and productivity growth. Subsequently, after a review of the main findings reported by the extant literature on the topic, we will set the hypotheses of our empirical investigation.

\section{Arguments for flexibility}

According to a supply-side, market-oriented perspective, labour market rigidities (e.g. collective bargaining, minimum wages, employment protection legislation, unemployment benefits) are preventing optimal functioning of the labour market. In this framework, stringent employment protection laws inhibit the efficient use of labour resources that, in turn, harm the dynamics of employment and productivity growth (Hopenhayn and Rogerson 1993). Conversely, labour market deregulation would benefit firms' production efficiency by reducing frictions due to the hiring and firing of workers and lowering the costs of labour adjustment (Bassanini and Ernst 2002; Nickell and Layard 1999). Furthermore, higher dismissal costs might stimulate a 'secondary' type of innovation, pushing the economy towards specialization in mature goods characterised by stagnant demand (Saint-Paul 1997, 2002). Similarly, more employment protection dampens firms' incentive to experiment with new, riskier and more profitable technologies, since high firing costs may hinder the numerical adjustment required by the new production technology (Bartelsman et al. 2016).

Moreover, employment protection affects the power relations between labour and capital. In this perspective, stringent labour protection may reduce profits after the introduction of a successful innovation as protected employees might have the bargaining power to renegotiate wages and appropriate a share of innovation (monopoly) rents. What follows is a reduction of the firms' incentive to foster technological progress (Malcomson 1997; Van Reenen 1996).

Focusing on the link between labour flexibility and productivity, some authors argued that in contexts of labour market imperfections and asymmetric information, temporary contracts 
are used to screen new workers to allow the selection of the most productive ones; the latter would be the only workers who are offered a permanent employment contract (Gibbons and Katz 1991; Lazear 1986). Labour flexibility would therefore promote the economic performance of firms inasmuch as permanent contracts are offered only to the most productive workers (Battisti and Vallanti 2013; Portugal and Varejão 2009).

Finally, firms searching for technical and professional skills (e.g. engineers, management consultants) might prefer hiring workers with a temporary or part-time contract. In this case, NSW could promote the diffusion of new ideas and knowledge that, in turn, enhances innovation activities and labour productivity (Arvanitis 2005).

Overall, according to the mechanisms discussed above, labour flexibility ultimately promotes productivity gains and technological change by: (i) reducing firms' labour adjustment costs, (ii) decreasing the cost of introducing innovations, (iii) fostering the diffusion of knowledge.

\section{Arguments against flexibility}

Several mechanisms that may induce an adverse effect of labour flexibility on productivity and technological progress. First, a high share of NSW might alter the incentives to invest in specific inputs, including human capital (Acemoglu and Pischke 1999; Arulampalam and Booth 1998; Belot et al. 2007; Booth et al. 2002). In fact, as within-firm career prospects are uncertain for non-standard workers, they discouraged from acquiring firm-specific knowledge, preferring to obtain general (i.e. portable) skills that may increase their future employability. Therefore, provision of employment protection may increase workers' incentive to invest in the firms' peculiar knowledge and, in turn, increase labour productivity. Nonetheless, stringent labour laws may stimulate investment in training, while the extensive use of non-standard contractual arrangements can reduce the incentive for employers to invest in employees' training and skill-building (Bassanini et al. 2007; OECD 2015). In turn, the lack of training opportunities implies lower knowledge accumulation (Ortega and Marchante 2010). In addition, if the probability of converting temporary to permanent contract is low, temporary workers may exert less effort, that in turn reduces productivity (Dolado et al. 2012). As argued by Lorenz (1992) and Buchele and Christiansen (1999), firm flexibility depends on trust between workers and employer; it follows that, in the absence of it, workers may be less cooperative and reluctant to disclose their 'proprietary knowledge', thus preventing its diffusion and decreasing firms' knowledge base. In this regard, after controlling for a series of observable individual characteristics (age, gender, socio-economic position). Svensson (2011) provides supporting evidence that non-standard workers display a relatively lower level of trust in comparison to standard workers.

Second, a higher share of NSW might weaken the firm's organizational capabilities, which are embedded in the firm's procedural knowledge (Dosi and Nelson 2010). From this perspective, stringent employment regulation may reduce excessive labour turnover strengthening the firm's knowledge base and fostering the development of firm capabilities (Kleinknecht 2020). In other terms, over time workers accumulate process-specific experience and refine their ability to perform tasks and solve problems, contributing to the accumulation of firm capabilities. Conversely, a rapid turnover of workers reduces the firm's organizational competencies, which are nested in the organization's procedural knowledge.

A third channel concerns the impact of numerical and wage flexibility on the remuneration of workers and, in turn, on firms' innovative capabilities. For example, in the efficiency wage models with asymmetric information - also in the absence of labour market institutions - firms 
offer wages that are above the equilibrium level in order to attract more productive workers and decrease shirking, especially in industries where monitoring costs are high (Shapiro and Stiglitz 1984). Likewise, according to the fair wage models, workers are more motivated and exert more effort if they receive a fair wage (Akerlof and Yellen 1990). More in general, nonstandard workers may be less cooperative in the innovation process if they cannot enjoy the benefits of it (Hoxha and Kleinknecht 2019; Kleinknecht 1998).

Following an evolutionary perspective, a fourth channel is related to the enhancement of the process of creative destruction due to more rigid labour markets. The decentralization of wage bargaining due to the rise of non-standard forms of employment and the consequent downward pressure on wages allows technological laggards to survive in the market relying on low labour cost rather than introducing innovative processes (Kleinknecht 2020). In other terms, whether higher wages reduce the profitability of introducing new technologies, they induce a cost increase which is more significant for technological laggards, that are consequently 'forced' to innovate or exit from the market (Nelson and Winter 1982).

Finally, a large literature adopting a Marxian and Kaldorian approach (Foley and Michl 1999; Kaldor and Mirrlees 1962) has stressed that more stringent employment protection institutions support workers in claiming better working conditions and higher wages, which increase firms' incentives to scrap the older vintages of machinery and foster capital-biased technological change (Basu 2010; Campbell and Tavani 2019; Marquetti 2004; Storm and Naastepad 2009, 2017). In particular, higher labour costs with respect to the investment price may promote the introduction of labour-saving innovation, a mechanism known as 'Ricardo effect' (Sylos Labini 1984).

\section{Review of the empirical evidence}

The extant empirical evidence on the topic is considerably large and findings vary according to the level of analysis, time periods and econometric techniques employed. In order to provide a detailed overview of the results obtained so far by the literature, Table A1 in Appendix reports a rather comprehensive summary of studies investigating the relationship between labour flexibility on the one side, and productivity and innovation performance on the other side.

Investigations which exploit firm-level data tend to suggest that the use of temporary and part-time contracts and job turnover significantly reduces productivity (Boeri and Garibaldi 2007; Cappellari et al. 2012; Devicienti et al. 2018; Lucidi and Kleinknecht 2010) and discourages R\&D investments and innovation (Franceschi and Mariani 2016; Grinza and Quatraro 2019; Kleinknecht et al. 2014; Michie and Sheehan 1999). Few studies report that temporary jobs (Arvanitis 2005; Zhou et al. 2011) and part-time work (Altuzarra and Serrano 2010) are positively correlated with the propensity to innovate. Other analyses, using German firm-level data, argue that the relationship is not monotonic, especially when temporary agency workers are used as a proxy of labour flexibility (Hirsch and Mueller 2012; Nielen 2016).

As for the evidence reported by industry-level studies, whether some of them find a negative relationship between the cost of hiring and firing and productivity growth (Bassanini et al. 2009; Scarpetta and Tressel 2004), others show that a more stringent labour market regulation promotes innovation and productivity growth, especially in coordinated market economies and high-tech industries (Bassanini and Ernst 2002). Consistently, a number of scholars find that the deregulation of temporary contracts seem to have an adverse impact on different measures of productivity (Damiani and Pompei 2010; Damiani et al. 2016; Lisi 2013; Lisi and Malo 2017; Ortega and Marchante 2010), whereas Auer et al. (2005) find a humpshaped relationship between job-tenure and productivity. 
As already noted, few studies distinguish between product and process innovations. In this regard, Michie and Sheehan (2003) show that all types of external flexibility are negatively correlated with process and total innovation, whereas no significant coefficient (although negative) is observed for product innovation. ${ }^{2}$ Conversely, Wachsen and Blind (2016) find that for those firms adopting a routinised innovation regime based on knowledge accumulation, both product and process innovation are negatively affected by a high labour turnover.

Overall, several theoretical arguments proposed by the literature and a large part of the extant empirical evidence on the topic suggest that the use of NSW by firms is likely to weaken the accumulation of knowledge, the latter being crucial to developing process and especially product innovation. Consistently, higher numerical flexibility, both internal and external, is likely to reduce firms' incentives to introduce both types of innovation. Against this background, we can formulate our first set of hypotheses:

Hla. An increasing share of NSW is expected to negatively affect the propensity to introduce product innovations, mainly incremental product innovations, by weakening the accumulation of knowledge generated by standard long-term employment relations.

H1b. An increasing share of NSW is expected to negatively affect the introduction of process innovations, as the availability of a highly adjustable workforce both in internal and external numerical terms can divert firms' cost-based competitiveness strategies from introducing labour-saving technologies to a dynamic reorganization of the workforce, while depressing the stock of knowledge needed to improve production efficiency.

\subsection{Heterogeneity in the effects of NSW}

It is worth emphasizing the importance of accounting for industry differences when dealing with the impact of NSW on innovation performance. Indeed, the use of NSW could affect productivity and innovation differently depending on the specificities of national and sectoral systems of innovation, production structures, and technological regimes (Dosi 1982; Freeman 1974; Malerba 2002, 2006).

As suggested by the evolutionary literature, the innovative behaviour of firms is fundamentally affected by the technological regime of industries, a concept that traces back to Nelson and Winter's (1982) definition of technological environment where productive organizations operate. A technological regime is essentially defined in terms of: i) appropriability conditions (degree of innovation protection to imitation); ii) cumulativeness conditions (level of serial correlation among innovations and innovative activities); iii) opportunity conditions (probability of innovating for a given investment in research) and iv) knowledge base (tacit, codified, easily transferable, complex, etc.) (Breschi et al. 2000; Malerba and Orsenigo 1997).

In other terms, the technological regime fundamentally affects the innovative capabilities and learning opportunities of firms belonging to different sectors. For example, traditional lowtech industries such as food, wood and paper tend to be characterised by a simpler knowledge base and lower levels of cumulativeness and appropriability, leading these sectors to follow mainly cost competitiveness strategies and engage in practices of price competition. Conversely, medium-high and high-tech sectors like chemical, pharmaceutical and computer industries feature a more complex knowledge base, a stronger technological cumulativeness

\footnotetext{
${ }^{2}$ Interestingly, the authors consider part-time employees, temporary and seasonal contracts as forms of external flexibility, consistently with our definition of non-standard workers.
} 
and lower opportunity conditions that limit the entry of new competitors. Consequently, these industries tend to be located on more stable, hierarchical and path-dependent innovation trajectories, characterised by creative accumulation patterns.

In this context, Kleinknecht et al. (2014), Wachsen and Blind (2016), and Hoxha and Kleinknecht (2020) find a negative impact of flexible work policies on innovation in industries that mostly rely on the accumulation of knowledge for technological progress - namely 'routinised' Schumpeter mark II-type sectors (Schumpeter 1942) -, while Vergeer et al. (2015) reach the same conclusion with reference to the (adverse) effects of flexible labour relations on labour productivity growth. Conversely, little or no impact of flexible work on the innovation performance emerged in less knowledge-intensive and 'garage business' industries - namely those characterised by a Schumpeter mark I model (Schumpeter 1934) -, where technological improvements mostly rely on more general and widely available knowledge. Lisi and Malo (2017) consider the differential effect of temporary employment in skilled and unskilled sectors and find that flexible work is more damaging in skilled sectors. On the same line, Cetrulo et al. (2019) disentangle the effect of temporary employment on product innovations by differentiating industries according to the level of 'cumulativeness of knowledge' using the classification of sectors provided by Peneder (2010). They show that, on the one hand, for industries in which cumulativeness is 'medium' or 'high', a higher share of flexible employment is associated with a significantly lower propensity to introduce product innovation. On the other hand, they find that for industries featured by a lower degree of knowledge accumulation labour flexibility tends to have a non-significant impact on innovation.

Building on this evidence, we assess whether the relationship between NSW and innovation differs across industries relying on the Revised Pavitt taxonomy developed by Bogliacino and Pianta (2010, 2016). This sectoral classification extends the Pavitt's (1984) taxonomy to service industries, allowing us to appropriately distinguish between high-tech and low-tech industries according to the structure of the market and the nature, sources and appropriability of knowledge. On this basis, we classify Science based and Specialised supplier industries as high-tech sectors, while Scale and information intensive and Supplier dominated industries are included in the low-tech sectoral cluster (Bramucci et al. 2017; Coveri and Pianta 2019; Guarascio et al. 2015; Guarascio and Pianta 2016; Reljic et al. 2019). ${ }^{3}$

Once stated our technology-based classification of sectors and took stock of the extant conceptual and empirical literature on technological regimes, we finally have all the ingredients to formulate our second hypothesis:

H2. An increasing share of NSW is expected to exert an incremental negative effect on the propensity to introduce both product and process innovation in high-tech industries, where past experiences and the acquisition of problem-solving capabilities are key drivers of technological progress.

\section{Data and descriptive evidence}

\subsection{The SID database}

The empirical analysis exploits the Sectoral Innovation Database (SID), which has been developed at the University of Urbino (Pianta et al. 2020) and merges different data sources at

\footnotetext{
${ }^{3}$ Table A5 in Appendix reports the complete list of sectors, including information on the Revised Pavitt class they belong to.
} 
industry-level, namely the Community Innovation Survey (CIS) and EU Labour Force Survey (EU LFS) provided by Eurostat, OECD's Structural Analysis Database (STAN) and World Input-Output Tables (WIOT) provided by WIOD.

The investigation is carried on five major European economies - France (FR), Germany (DE), Italy (IT), the Netherlands (NL) and the United Kingdom (UK) - over the period 19942016. Data are available for the two-digit NACE Rev. 2 classification for 18 manufacturing (from 10 to 33 NACE Rev. 2) and 23 service sectors (from 45 to 82 NACE Rev. 2) (see Table A5 in Appendix) and refer to total activities of industries. To fulfil the requisite conditions for comparability, all data before 2008 have been converted into NACE Rev. 2 taking advantage of the conversion matrix provided by Perani and Cirillo (2015). All the monetary variables have been deflated (base year 2000), converted in euros and adjusted for PPP using the index provided in Stapel et al. $(2004,5)$.

With regards to innovation variables, data are drawn from the Community Innovation Survey, a comprehensive data source on firm innovation activities used in a vast number of empirical studies (Barbieri et al. 2018; Cirillo 2017, 2018; Guarascio and Pianta 2016). This dataset allows to distinguish innovation along several dimensions and in particular between product and process innovation on the one hand, and between input and output of innovation on the other hand. Given the aim of this work, we use investment in R\&D and expenditure in machinery and equipment as proxies of innovation inputs, and the share of firms in the sector that introduced new products and new processes as variables capturing innovation outputs. As already stated in Section 2.1, we conceive the introduction of product innovation as mainly dictated by a knowledge-based competitiveness strategy aimed at increasing the market share and opening of new markets; conversely, process innovation is regarded as a cost-based competitiveness strategy whose purpose is to improve production efficiency through the adoption of labour-saving technologies (Pianta 2001).

Our main variable of interest, namely the share of non-standard workers (NSW) employed in the sector, has been constructed using microdata from the EU Labour Force Survey. In particular, we built this variable by cross-tabulating data on the basis of the permanency of the job (permanent and temporary) and for the hours worked (full-time and part-time) at industrylevel. ${ }^{4}$ Therefore, our key variable is expressed as the share of full-time temporary, part-time permanent and part-time temporary employees over the total number of employees in the sector. We argue that this variable can represent an appropriate indicator of the overall adoption of non-standard forms of employment in industries. ${ }^{5}$

Moreover, our model includes a set of industry-specific control variables on factors which can arguably contribute to the innovation performance of sectors, namely the average firm size, the dynamics of effective demand, the share of imported high-tech intermediate inputs, the share of managers and of manual workers (capturing the occupational structure of industries) and, as a further robustness check, the share of university graduates. Table A2 in Appendix

\footnotetext{
${ }^{4}$ Using the ILO's (2016) employment status, we restrict our analysis to employees, meaning that self-employed and family workers are left out of the investigation.

${ }^{5}$ Unfortunately, limited data availability does not allow us to distinguish between the voluntary and involuntary share of NSW, nor by hours worked for part-time workers. However, according to data provided by Eurostat, involuntary part-time workers accounted for roughly one third of total part-time employment in the EU19 in 2016 , spanning from a minimum equal to $9.9 \%$ in the Netherlands - nonetheless, it is worth noting that in this country the share of part-time workers over total employees is remarkably high - up to a maximum well over $60 \%$ in Italy and Spain. These figures support us in including part-time work among non-standard, low-quality jobs (Green and Livanos 2017).
} 
offers a detailed description of the sources and methodology used for the construction of these variables, while the summary statistics are reported by Table A3 in Appendix.

In this context, it is just worth noting the inclusion of the variable related to the foreign sourcing of high-tech intermediate inputs, which allows to account for the modern international fragmentation of production (Milberg and Winkler 2013) while also capturing its technological dimension. In particular, we took advantage of the offshoring indicator proposed by Feenstra and Hanson (1996) as amended by Guarascio et al. (2015) to discriminate imported intermediate inputs according to their technological content. By exploiting the World InputOutput Tables (WIOT) provided by WIOD (Timmer et al. 2015), we thus built this indicator by computing the ratio between the sum of the expenditure devoted by each industry to the acquisition of intermediate inputs from foreign high-tech industries over the expenditure for the total (domestically produced and foreign) intermediate inputs used for production by each sector.

The dataset is a panel over six periods built according to the following time structure. Dependent variables, i.e. the share of product and process innovators, refer to the following five periods: 1998-2000, 2002-2004, 2008-2010, 2012-2014, 2014-2016. Since the regressors are introduced with a one-period lag to avoid simultaneity-related endogeneity, the variables related to innovation inputs (i.e. expenditure in $R \& D$, and expenditure in machinery and equipment) refer to 1994-1996, 1998-2000, 2002-2004, 2008-2010, 2012-2014. According to the same rationale, the share of non-standard workers - namely our key explanatory variable as well as the share of managers, of manual workers and of university graduates - used as controls - are introduced with a lag, reason why they refer to the following years: 1996, 2000, 2003, 2008, 2012. Variables related to value added and average labour cost are also introduced with a lag, since they are computed as the average annual compound growth rate over the following periods: 1996-2000, 2000-2003, 2003-2008, 2008-2012, 2012-2014. Consistently, the variable related to the foreign sourcing of high-tech intermediate inputs is computed as the simple difference between the last and first year of each of the same periods. Finally, average firm size at industry-level is computed over the periods the dependent variables refer to. ${ }^{6}$

\subsection{Descriptive evidence}

An illustration of the use of NSW by European countries is offered in this subsection, which also provides evidence on the evolution of NSW components and the relationship between NSW and industries' innovation performance.

Figure 1 reports the share (\%) of NSW over the total number of employees for the five European countries under investigation over the period 1995-2018. The graph shows an increase of about 11 percentage points (p.p.) in the share of non-standard jobs since 1995. Although the standard (i.e. permanent and full-time) type of work is still prevalent in most of the European countries, more than $30 \%$ of employees in 2018 were in a non-standard employment relationship. In addition, all three NSW subcategories exhibited an upward trend, with the share of part-time permanent jobs representing the main component of NSW - it passed from $14 \%$ in 1995 to $19 \%$ in 2018. In this context, Italy experienced the greater increase in the share of temporary workers (+8 p.p.), followed by France and the Netherlands. Most

\footnotetext{
${ }^{6}$ The temporal structure of the database is firstly due to the frequency according to which Eurostat collects the innovation surveys and makes them available. The variable related to the expenditure for new machinery and equipment contains missing values for the first two CIS waves by construction; however, missing values are homogeneously distributed across countries in service industries.
} 
notably, the share of the most vulnerable category - part-time employees with temporary contracts - more than doubled over the reference period, with the Netherlands registering the largest increase (+10 p.p.) and reaching a share of $16 \%$ in 2018.

\section{INSERT FIGURE 1 HERE.}

Figure 2 shows the general increase in the share of NSW for the five European countries under investigation. The Netherlands reported the highest share of NSW all over the period, with a share of NSW ranging from $40 \%$ in 1995 to nearly $60 \%$ in 2018 . Germany follows, which recorded an upward trend from 1995 to 2006 and a flat one thereafter, so that the share of NSW in the last decade has been little less than 40\%. Moreover, since 1995 the share of NSW has surged in Italy (+23 p.p.) to the point that one in three employees has a non-standard job in 2018. Finally, the increase in the share of NSW in France and the UK has been relatively modest over the period.

\section{INSERT FIGURE 2 HERE.}

It is also worth highlighting that over the reference period the share of non-standard contractual arrangements has averagely increased across almost all industries of the European economies considered. Nonetheless, remarkable differences exist between high- and low-tech industry clusters in terms of use of NSW. As reported by Table A4 in Appendix, low-tech industries rely more on the latter than high-tech industries, being the share of non-standard workers on average equal to $29.48 \%$ and $19.67 \%$, respectively. ${ }^{7}$ Figure 3 shows the negative relationship between the share of NSW and the introduction of product (left-hand panel) and process (right-hand panel) innovation at industry-level. Notably, the graphs also highlight that the downward sloping fitted line is steeper for high-tech than for low-tech industries with regards to product innovation, suggesting that non-standard contractual arrangements are more harmful to the introduction of product innovation in high-tech industries. Conversely, a similar pattern does not emerge with reference to process innovation.

\section{INSERT FIGURE 3 HERE.}

\section{The empirical model}

Our empirical strategy aims at identifying the effect of the use of non-standard forms of employment on the propensity to introduce both product and process innovation by firms belonging to the European industries included in the sample. On the basis of the conceptual framework discussed in Section 2, the relationship between NSW and the innovation performance of industries can be formally written as follows:

ProductInnov $_{i j t}=\beta_{0}+\beta_{1} N S W_{i, j, t-1}+\beta_{2} \operatorname{InvRD}_{i, j, t-1}+\beta_{3} \operatorname{ExpMACH}_{i, j, t-1}+\beta_{4} \operatorname{SIZE}_{i, j, t}+\beta_{5} \Delta V A_{i, j, t-1}+$ $\beta_{6} \Delta W_{i, j, t-1}+\beta_{7} \Delta$ HTInputs $_{i, j, t-1}+\beta_{8}$ Skills $_{i, j, t-1}+\mu_{i}+\chi_{j}+\tau_{t}+\varepsilon_{i, j, t}$

\footnotetext{
${ }^{7}$ Results of the analysis of variance (ANOVA) also confirm that the variation between the two clusters (i.e. highand low-tech industries) is higher than within-variation in terms of both innovation output (product and process innovation) and innovation inputs ( $R \& D$ investments and expenditure in machinery). Data are available upon request.
} 
ProcessInnov $_{i j t}=\beta_{0}+\beta_{1} N S W_{i, j, t-1}+\beta_{2} \operatorname{InvRD}_{i, j, t-1}+\beta_{3} \operatorname{ExpMACH}_{i, j, t-1}+\beta_{4} \operatorname{SIZE}_{i, j, t}+\beta_{5} \Delta V A_{i, j, t-1}+$ $\beta_{6} \Delta W_{i, j, t-1}+\beta_{7} \Delta$ HTInputs ${ }_{i, j, t-1}+\beta_{8}$ Skills $_{i, j, t-1}+\mu_{i}+\chi_{j}+\tau_{t}+\varepsilon_{i, j, t}$

where $i, j$ and $t$ are indices for industry, country and time period, respectively. $\mu$ stands for the Pavitt dummies which control for the industry's technological regime; $\chi$ for the country dummies, and $\tau$ for the time dummies, while $\varepsilon$ is the error term.

Equations (1) and (2) allow to test our first set of research hypotheses, i.e. a higher share of non-standard workers $(N S W)$ is associated with a lower propensity to introduce product (hypothesis Hla) and process innovation (hypothesis $\mathrm{Hlb}$ ). In addition, as the equations present the same list of regressors, they allow to assess the different impact of the latter on the two kinds of innovation. In particular, since the introduction of product innovation (ProductInnov) is conceived as the outcome of a technology-driven competitiveness strategy, we expect investment in $\mathrm{R} \& \mathrm{D}$ (InvRD) to show a positive and significant coefficient, while expenditure in new machinery and equipment $(\operatorname{ExpMACH})$ plays a more negligible role in this context. Conversely, process innovation (ProcessInnov) is regarded as the result of costbased competitiveness strategies, reason why we expect that the embodied technological progress captured by the expenditure in new machinery reports a positive and significant coefficient in the equation (2)'s estimation results (Pianta 2001). With regards to control variables, SIZE is the average firm size in the sector; $V A$ stands for value added, which proxies the industry-specific dynamics of effective demand; and $W$ is the compound average annual growth rate of labour compensation. Finally, HTInputs is the share of intermediate inputs imported from foreign high-tech sectors over the total intermediate inputs used for production by each industry, while Skills are proxied by two variables, namely the share of managers and of manual workers, allowing to control for the occupational structure of industries (see Table A2 in Appendix).

Moreover, building on the framework drawn in previous sections, we amend the previous regressions to test our second research hypothesis, i.e. a higher share of NSW has an incremental negative effect on the propensity to introduce product and process innovation in high-tech sectors (hypothesis H2). Formally, we estimate the following equations:

ProductInnov $_{i j t}=\beta_{0}+\beta_{1} N S W_{i, j, t-1}+\beta_{2} N S W_{i, j, t-1} *$ HighTech $_{i}+\beta_{3}$ InvRD $_{i, j, t-1}+\beta_{4}$ ExpMACH $_{i, j, t-1}+$ $\beta_{5} \operatorname{SIZE}_{i, j, t}+\beta_{6} \Delta V A_{i, j, t-1}+\beta_{7} \Delta W_{i, j, t-1}+\beta_{8} \Delta$ HTInputs $_{i, j, t-1}+\beta_{9}$ Skills $_{i, j, t-1}+\mu_{i}+\chi_{j}+\tau_{t}+\varepsilon_{i, j, t}$

ProcessInnov $_{i j t}=\beta_{0}+\beta_{1} N S W_{i, j, t-1}+\beta_{2} N_{S W} W_{i, j, t-1} *$ HighTech $_{i}+\beta_{3} \operatorname{InvRD}_{i, j, t-1}+\beta_{4}$ ExpMACH $_{i, j, t-1}+$ $\beta_{5} \operatorname{SIZE}_{i, j, t}+\beta_{6} \Delta V A_{i, j, t-1}+\beta_{7} \Delta W_{i, j, t-1}+\beta_{8} \Delta H T$ Inputs $_{i, j, t-1}+\beta_{9}$ Skills $_{i, j, t-1}+\mu_{i}+\chi_{j}+\tau_{t}+\varepsilon_{i, j, t}$

where HighTech is a dichotomous variable which allows to distinguish industries into two broad technology-based clusters, i.e. the high-tech and the low-tech cluster, on the basis of the Revised Pavitt taxonomy provided by Bogliacino and Pianta (2010, 2016).

With regards to the empirical methodology, we adopt the following identification strategy. First, all specifications include country, time and Pavitt dummies to control for institutional, time and technological heterogeneities. ${ }^{8}$ Time dummies are essential to control for the business cycle and avoid that time-specific effects being captured by the error term and raising endogeneity concerns. Most importantly, industries remarkably differ in terms of technological

\footnotetext{
${ }^{8}$ Available Employment Protection Legislation (EPL) indicators, frequently used in empirical studies on this topic, vary only across countries but do not vary significantly over time. It follows that the EPL indicator is highly correlated with country dummies and we prefer to use the latter in order to control for all unobservable heterogeneities (e.g. welfare system, cultural differences and social capital).
} 
regimes (Breschi et al. 2000; Malerba and Orsenigo 1997;). In this context - next to our rich set of control variables capturing economic and occupational features of sectors - Pavitt dummies are crucial, as allow to explicitly account for the structural patterns of industries while avoiding the risk of multicollinearity potentially induced by the inclusion of a large number of sector-specific dummies. In addition, too many dummy variables may prevent the model from getting a sufficient number of degrees of freedom for adequately powerful statistical tests.

Second, all explanatory variables are lagged by one period to take into account the time required by innovation inputs to materialise in innovation outputs and to reduce the risk of simultaneity-related endogeneity bias (Grinza and Quatraro 2019; Zhou et al. 2011). Third, we perform estimates exploiting the Weighted Least Squares (WLS) estimator, using the number of employees (as observed in the first year of each time period) as weights (Bassanini and Ernst 2002; Cetrulo et al. 2019); otherwise, the consistency of the estimator might be affected by the asymmetric information provided by industry data, which are grouped data of unequal size (Wooldridge 2002). Fourth, we carry out all the estimations applying heteroskedasticity- and autocorrelation-robust standard errors.

\section{Results}

Table 1 provides the estimation results of the model with the share of firms introducing product innovation as dependent variable. The coefficient related to the share of NSW is stable across specifications and results always negative and statistically significant. This finding thus seems to confirm our first hypothesis (Hla), suggesting that a higher share of NSW is detrimental to the introduction of product innovation as reduces the pace of knowledge accumulation. According to the specification reported by column 4, a one percentage point increase in the share of NSW is associated with a 0.228 percentage point decrease in the share of firms introducing product innovations.

As expected, Table 1 also shows that R\&D expenditure has a positive and significant coefficient, while the expenditure in machinery and equipment exhibit a positive but not significant one. Moreover, the average firm size - a proxy for market structure - reports a positive and significant coefficient, in line with the Schumpeter Mark II model; while the growth rate of value added - a proxy for effective demand - and of labour compensation turn out not significant (column 2). Notably, column 3 shows that an increase in the share of imported intermediate inputs from foreign high-tech sectors results having a positive and significant effect on the introduction of product innovation, confirming the international technological spillovers which may accrue to firms from the cross-border sourcing of knowledge-intensive goods and services (Colantone and Crinò 2014; Pöschl et al. 2016; Tajoli and Felice 2018). Finally, column 4 also controls for the occupational structure of industries, reporting that the share of manual workers has a negative and significant coefficient while the share of managers is not statistically different from zero.

\section{INSERT TABLE 1 HERE.}

Table 2 focuses on the impact of non-standard forms of employment on the introduction of process innovation. The share of NSW exhibits a negative and significant coefficient across all specifications, with a magnitude in column 4 which is close to that found in the previous table. This result therefore suggests a confirmation of our hypothesis $H 1 b$, which guessed the detrimental impact of employing workers with non-standard contractual arrangements on the 
propensity to introduce process innovations, as using NSW undermines firms' incentives to adopt labour-saving technologies.

As expected, Table 2 shows that the coefficient of R\&D expenditure loses significance with respect to the previous table, while the expenditure in new machinery and equipment turns out always positive and significantly associated with process innovation. Moreover, while the positive and significant coefficient of the average firm size is reasserted, column 2 shows that the coefficient related to the growth rate of value added is negative and slightly significant. This result seems to support the idea that innovations bunch during downswings of the business cycle, as during upswings firms may survive exploiting rents given by a sustained demand dynamics, which in turn would reduce the incentives to introduce new technologies (Filippeti and Archibugi 2011; Kleinkhnecht 1982; Mensch 1979). Most notably, the growth rate of labour compensation reports a positive and significant coefficient, confirming that higher wages rise firms' incentive to introduce process innovation aimed at adopting labour-saving technologies (Sylos Labini 1984). Finally, column 4 shows that the variable capturing the foreign sourcing of high-tech intermediate inputs is not significant, while the share of manual workers has a negative and significant coefficient as in Table 1.

\section{INSERT TABLE 2 HERE.}

As formulated by our second research hypothesis $(\mathrm{H} 2)$, the effect of NSW on industries' innovation performance is expected to be heterogeneous according to the technological regime of industries. Therefore, Table 3 reports the estimation results of equation (3), which includes the interaction between the share of NSW and a 'high-tech dummy' assuming value equal to one whether industries are classified as Science Based or Specialised Suppliers, and zero otherwise. The coefficients of both the share of NSW and the interaction term between the latter and the high-tech dummy are negative and strongly significant in all specifications, suggesting that the use of NSW is more detrimental to the introduction of product innovation in high-tech sectors compared to low-tech ones. This finding is consistent with previous evidence on the more harmful effect of flexible labour on technological change in industries where the accumulation of firm-specific knowledge plays a major role in the innovation process (Cetrulo et al. 2019; Hoxha and Kleinknecht 2020; Kleinknecht et al. 2014; Wachsen and Blind 2016). The coefficients of control variables maintain their sign and statistical relevance, with the coefficient of the share of manual workers being the only which loses significance.

\section{INSERT TABLE 3 HERE.}

Table 4 reports the estimation results of equation (4), which has the share of firms introducing process innovation as dependent variable and includes the interaction term between the share of NSW and the 'high-tech dummy' to allow the former term's coefficient to vary between technology-based industry clusters. First of all, previous results on the sign and significance of control variables are largely reaffirmed. Most importantly, although the share of NSW always maintains a negative and significant coefficient, the interaction term turns out negative but not significant in all specifications. In other terms, we fail to detect an incremental negative impact of non-standard contractual arrangements on the propensity to foster process 
innovation by high-tech industries, meaning that a higher share of NSW equally reduces the propensity to introduce process innovation in high- and low-tech sectors.

A possible interpretation of this finding - which does not support our second research hypothesis - is that a larger use of non-standard contractual arrangements by firms disrupts the accumulation of workers' expertise which is fundamental to high-tech industries for introducing new knowledge-intensive products, being the latter the outcome of technologyoriented competitiveness strategies (Pianta 2001). Conversely, one might argue that a higher share of NSW reduces firms' incentive to introduce labour-saving technologies regardless of the technological regime of the industry they belong to, as process innovations are motivated by cost-based competitiveness strategies pursued by high- and low-tech industries alike.

\section{INSERT TABLE 4 HERE.}

As a robustness check, we test the sensitivity of our findings to the inclusion of the share of university graduates as a proxy for the level of human capital. In this way, we control for the skill structure of industries as further factor which may affect their technological capabilities (Hirsch and Mueller 2012; Zhou et al. 2011). Column 1 and 2 of Table A6 in Appendix report the results of the regressions for product innovation, while column 3 and 4 do the same for process innovation. All columns largely confirm our previous findings on the detrimental impact of the use of NSW on both product and process innovation, with the share of university graduates always exhibiting a positive but not significant coefficient. Table A7 in Appendix presents the same structure of Table A6 though it also includes the interaction term which allows the coefficient of the share of NSW to vary between high- and low-tech industry clusters. Once again, results confirm our previous findings, showing that a higher share of NSW has an incremental adverse effect on the launch of new products by high-tech industries, while a larger use of NSW equally discourages the introduction of process innovation in highand low-tech sectors.

\section{Conclusions}

The implementation of structural labour market reforms in European economies has given rise to a plethora of new flexible contractual arrangements, multiplying the atypical forms of employment and resulting in the spread of the so-called non-standard work (NSW). In this context, a large body of literature investigated the relationship between the labour market deregulation and the dynamics of labour productivity and technological change.

In this work we firstly provided an extensive review of the theoretical literature on this topic, offering a systematization of the economic arguments for and against labour flexibility as a factor able to promote or hinder innovation. Secondly, we reviewed the extant empirical evidence on the effect of labour flexibility on innovation and productivity performance, focusing on both firm- and industry-level studies.

Moreover, we provided an empirical analysis on the relationship between non-standard forms of employment and the propensity to introduce both product and process innovation for 41 industries belonging to five European countries (Germany, France, Italy, the Netherlands and the UK) over the period 1994-2016. To this aim, we introduced a new variable encompassing both temporary and part-time work as to properly capture the evolution of nonstandard work, while controlling for the technological regime of sectors as well as for a wide range of other determinants of technological change. Furthermore, we tested if the impact of 
NSW on innovation performance differs across sectors, emphasizing the heterogeneous role that the accumulation of knowledge plays in promoting technological change in different industry clusters.

Our results support our first research hypothesis on the adverse effect that using nonstandard forms of employment has on firms' incentives to foster technological change, as we find that a higher share of NSW has a negative and statistically significant impact on the share of firms introducing product and process innovation. Furthermore, we find a partial confirmation of our second research hypothesis, according to which increasing the share of NSW has an incremental negative effect on the introduction of product and process innovation in high-tech industries compared to low-tech ones. In fact, while we detect an incremental adverse effect of the share of NSW on the introduction of product innovation by high-tech industries, we do not find a statically significant incremental effect of the adoption of NSW on process innovation by the latter industries compared to low-tech ones.

On the one side, our results are consistent with previous findings (Kleinknecht et al. 2014; Cetrulo et al. 2019; Hoxha and Kleinknecht 2020) documenting the adverse consequences of NSW on the introduction of product innovation for those industries for which the accumulation of firm-specific knowledge is essential to sustain the pace of technological change. On the other side, our findings suggest that a greater share of workers employed under non-standard contractual arrangements equally discourages the introduction of process innovation in highand low-tech industries. A possible interpretation of this finding is related to the different role played by the accumulation of workers' expertise for industries which pursue distinct competitiveness strategies and are marked by different technological regimes. In particular, the accumulation of skills and capabilities by workers - which has been shown to be disrupted by an increasing use of flexible labour - is likely to be crucial for the introduction of new knowledge-based products by high-tech industries pursuing technology-oriented competitiveness strategies (Pianta 2001); conversely, the introduction of labour-saving technologies is aimed at seeking cost reductions by both high- and low-tech sectors and is equally diverted by the use of NSW.

Overall, the evidence provided suggest that a larger use of non-standard contractual arrangements significantly reduces technological progress. Contrary to the objectives that market-oriented policy recommendations promised to achieve - namely to promote innovation and firms' competitiveness - the greater labour flexibility seems having led to the opposite result of depressing the pace of technological change while favouring the spread of low-quality jobs in Europe.

\section{Acknowledgments}

Armanda Cetrulo and Jelena Reljic acknowledge support from European Union's Horizon2020 research and innovation program under grant agreement No. 822781 GROWINPRO - Growth Welfare Innovation Productivity. 


\section{References}

Acemoglu, D., and Pischke, J.S. 1999. "Beyond Becker: Training in Imperfect Labour Markets.” Economic Journal 109(453): 112-142.

Addison, J.T., and Surfield, C.J. 2009. "Atypical work and employment continuity." Industrial Relations: A Journal of Economy and Society, 48(4), 655-683.

Akerlof, G.A., and Yellen J.L. 1990. "The Fair Wage-Effort Hypothesis and Unemployment." The Quarterly Journal of Economics 105(2), 255-283.

Altuzarra, A., and Serrano, F. 2010. "Firms Innovation Activity and Numerical Flexibility." Industrial and Labor Relations Review 63(2): 327-339.

Arulampalam, W., and Booth, A. L. 1998. "Training and labour market flexibility: is there a trade-off?" British Journal of Industrial Relations, 36(4): 521-536.

Arvanitis, S. 2005. "Modes of Labor Flexibility at Firm Level: Are There Any Implications for Performance and Innovation? Evidence for the Swiss Economy." Industrial and Corporate Change 14(6): 993-1016.

Atkinson, J. 1984. "Manpower Strategies for Flexible Organisations." Personnel Management 16(8): $28-31$.

Auer, P., Berg, J. and Coulibaly, I. 2005. "Is a Stable Workforce Good for Productivity?" International Labour Review 144(3): 319-343.

Barbieri, L., Piva, M., and Vivarelli, M. 2018. "R\&D, Embodied Technological Change, and Employment: Evidence from Italian Microdata." Industrial and Corporate Change 28(1): 203-218.

Bartelsman, E.J., Gautier, P.A., and Wind, J.D. 2016. "Employment Protection, Technology Choice, and Worker Allocation." International Economic Review 57(3): 787-826.

Bassanini, A. 2002. "Labour Market Regulation, Industrial Relations and Technological Regimes: A Tale of Comparative Advantage." Industrial and Corporate Change 11(3): 391-426.

Bassanini, A., Booth, A., Brunello, G., De Paola, M., and Leuven, E. 2007. "Workplace Training in Europe." In Brunello, G., Garibaldi, P., and Wasmer, E. (eds) Education and Training in Europe, 143-323. Oxford: Oxford University Press.

Bassanini, A., Nunziata, L., and Venn, D. 2009. "Job Protection Legislation and Productivity Growth in OECD Countries." Economic Policy 24(58): 349-402.

Battisti, M., and Vallanti, G. 2013. "Flexible wage contracts, temporary jobs, and firm performance: Evidence from Italian firms." Industrial Relations: A Journal of Economy and Society 52(3): 737-764.

Basu, D. 2010. "Marx-Biased Technical Change and the Neoclassical View of Income Distribution." Metroeconomica 61(4): 593-620.

Becker, B.A, and Huselid, M.A. 1998. "High Performance Work Systems and Firm Performance: A Synthesis of Research and Managerial Applications." Research in Personnel and Human Resources Management 16: 53-101.

Belot, M., Boone, J., and Van Ours, J. 2007. "Welfare-Improving Employment Protection." Economica 74(295): 381-396. 
Boeri, T., and Garibaldi, P. 2007. "Two Tier Reforms of Employment Protection: A Honeymoon Effect?" Economic Journal 117(521): F357-F385.

Bogliacino, F., and Pianta, M. 2010. "Innovation and Employment: A Reinvestigation Using Revised Pavitt Classes." Research Policy 39(6): 799-809.

Bogliacino, F., and Pianta, M. 2016. "The Pavitt Taxonomy, Revisited: Patterns of Innovation in Manufacturing and Services." Economia Politica: Journal of Analytical and Institutional Economics 33(2): 153-180.

Bramucci, A., Cirillo, V., Evangelista, R., and Guarascio, D. 2017. "Offshoring, Industry Heterogeneity and Employment." Structural Change and Economic Dynamics. Available online 17 September 2017. DOI: 10.1016/j.strueco.2017.09.002

Brancaccio, E., Garbellini, N., and Giammetti, R. 2018. "Structural Labour Market Reforms, GDP Growth and the Functional Distribution of Income." Structural Change and Economic Dynamics 44: 34-45.

Breschi, S., Malerba, F., and Orsenigo, L. 2000. "Technological Regimes and Schumpeterian Patterns of Innovation.” Economic Journal 110(463): 388-410.

Bryson, A. 2013. “Do Temporary Agency Workers Affect Workplace Performance?” Journal of Productivity Analysis 39(2): 131-138.

Buchele, R., and Christiansen, J. 1999. "Labor Relations and Productivity Growth in Advanced Capitalist Economies." Review of Radical Political Economics 31(1): 87-110.

Campbell, T., and Tavani, D. 2019. "Marx-biased Technical Change and Income Distribution: A Panel Data Analysis." Metroeconomica 70(4): 655-687.

Cappellari, L., Dell'Aringa, C., and Leonardi, M. 2012. "Temporary Employment, Job Flows and Productivity: A Tale of Two Reforms.” Economic Journal 122(562): F188-F215.

Cappelli, P., and Keller, J.R. 2013. "Classifying Work in the New Economy." Academy of Management Review 38(4): 575-596.

Cetrulo, A., Cirillo, V. and Guarascio, D. 2019. "Weaker Jobs, Weaker Innovation. Exploring the Effects of Temporary Employment on New Products." Applied Economics 51(59): 6350-6375.

Cirillo, V. 2017. "Technology, Employment and Skills." Economics of Innovation and New Technology 26(8): 734-754.

Cirillo, V. 2018. "Job Polarization in European Industries." International Labour Review 157(1): 39-63.

Cirillo, V., and Ricci, A. 2020. "Heterogeneity Matters: Temporary Employment, Productivity and Wages in Italian Firms." Economia Politica. Available online 5 September 2020. DOI: $10.1007 / \mathrm{s} 40888-020-00197-2$

Colantone, I., and Crinò, R. 2014. "New imported inputs, new domestic products." Journal of International Economics 92(1): 147-165.

Coveri, A., and Pianta, M. 2019. “Technology, Profits and Wages.” LEM Papers Series 35.

Damiani, M., and Pompei, F. 2010. "Labour Protection and Productivity in the EU Economies: 1995-2005.” The European Journal of Comparative Economics 7(2): 373-411.

Damiani, M., Pompei, F., and Ricci, A. 2016. "Temporary Employment Protection and Productivity Growth in EU Economies.” International Labour Review 155(4): 587-622. 
Devicienti, F., Grinza, E., and Vannoni, D. 2018. "The Impact of Part-Time Work on Firm Productivity: Evidence from Italy." Industrial and Corporate Change 27(2): 321-347.

Dolado, J. J., Ortigueira, S. and Stucchi, R. 2012. "Does Dual Employment Protection Affect TFP? Evidence from Spanish Manufacturing Firms." CEPR Discussion Paper DP8763.

Dosi, G. 1982. "Technological Paradigms and Technological Trajectories." Research Policy 11(3): 147-162.

Dosi, G., and Nelson, R.R. 2010. "Technical Change and Industrial Dynamics as Evolutionary Processes." In Hall, B. H., and Rosenberg N. (eds) Handbook of the Economics of Innovation, Vol. 1, 51-127. North Holland: Elsevier

Feenstra, R.C., and Hanson, G.H. 1996. "Globalization, Outsourcing, and Wage Inequality." American Economic Review, 86(2), 240-5.

Filippetti, A., and Archibugi, D. 2011. "Innovation in Times of Crisis: National Systems of Innovation, Structure, and Demand." Research Policy 40(2): 179-192.

Foley, D., and Michl, T. 1999. Growth and Distribution. Cambridge, MA: Harvard University Press.

Franceschi, F., and Mariani, V. 2016. "Flexible Labor and Innovation in the Italian Industrial Sector." Industrial and Corporate Change 25(4): 633-648.

Freeman, C. 1974. The Economics of Industrial Innovation. Harmondsworth: Penguin.

Giannetti, C., and Madia, M. 2013. "Work Arrangements and Firm Innovation: Is There Any Relationship?" Cambridge Journal of Economics 37(2): 273-297.

Gibbons, R., and Katz, L.F. 1991. "Layoffs and lemons." Journal of Labor Economics 9(4): 351-380.

Green, A., and Livanos, I. 2017. "Involuntary Non-Standard Employment in Europe." European Urban and Regional Studies 24(2): 175-192.

Grinza, E., and Quatraro, F. 2019. “Workers' Replacements and Firms' Innovation Dynamics: New Evidence from Italian Matched Longitudinal Data.” Research Policy 48(9): 103804.

Guarascio, D., and Pianta, M. 2016. "The gains from technology: new products, exports and profits." Economics of Innovation and New Technology 26(8): 779-804.

Guarascio, D., Pianta, M., Lucchese, M. and Bogliacino, F. 2015. "Business Cycles, Technology and Exports.” Economia Politica 32(2): 167-200.

Hipp, L., Bernhardt, J., and Allmendinger, J. 2015. "Institutions and the Prevalence of Nonstandard Employment.” Socio-Economic Review 13(2): 351-377.

Hirsch, B., and Mueller, S. 2012. "The Productivity Effect of Temporary Agency Work: Evidence from German Panel Data.” Economic Journal 122(562): 216-236.

Hopenhayn, R. 1993. "Job Turnover and Policy Evaluation." Journal of Political Economy 101(5): 915-938.

Hoxha, S., and Kleinknecht, A. 2019. "Do Trustful Labor-Management Relations Enhance Innovation? Evidence from German WSI Data." Review of Social Economy. Available online 25 September 2019. DOI: 10.1080/00346764.2019.1662936

Hoxha, S., and Kleinknecht, A. 2020. "When Labour Market Rigidities Are Useful for Innovation. Evidence from German IAB Firm-Level Data." Research Policy 49(7): 104066. 
International Labour Office (ILO). 2016. Non-Standard Employment around the World: Understanding Challenges, Shaping Prospects. Geneva: ILO.

Kaldor, N., and Mirrlees, J.A. 1962. "A new model of economic growth." The Review of Economic Studies 29(3): 174-192.

Kalleberg, A.L. 2001. "Organizing Flexibility: The Flexible Firm in a New Century.” British Journal of Industrial Relations 39(4): 479-504.

Kalleberg, A.L. 2011. Good jobs, bad jobs: The rise of polarized and precarious employment systems in the United States, 1970s-2000s. New York: Russell Sage Foundation.

Kleinknecht, A. 1982. Innovation patterns in crisis and prosperity: Schumpeterian long cycles reconsidered. MacMillan: London.

Kleinknecht, A. 2020. "The (Negative) Impact of Supply-Side Labour Market Reforms on Productivity: An Overview of the Evidence." Cambridge Journal of Economics 44(2): 445-464.

Kleinknecht, A., Oostendorp, R.M., Pradhan, M.P., and Naastepad, C.W.M. 2006. "Flexible Labour, Firm Performance and the Dutch Job Creation Miracle." International Review of Applied Economics 20(2): 171-187.

Kleinknecht, A., van Schaik, F.N., and Zhou, H. 2014. "Is Flexible Labour Good for Innovation? Evidence from Firm-Level Data." Cambridge Journal of Economics 38(5): 1207-1219.

Lazear, E.P. 1986. “Salaries and piece rates.” Journal of Business 59(3): 405-431.

Lisi, D. 2013. "The Impact of Temporary Employment and Employment Protection on Labour Productivity: Evidence from an Industry-Level Panel of EU Countries." Journal for Labour Market Research 46(2): 119-144.

Lisi, D., and Malo, M.A. 2017. "The Impact of Temporary Employment on Productivity." Journal for Labour Market Research 50(1): 91-112.

Lorenz, E. 1992. "Trust and the Flexible Firm: International Comparisons." Industrial Relations: A Journal of Economy and Society 31: 455-472.

Lucidi, F., and Kleinknecht, A. 2009. "Little Innovation, Many Jobs: An Econometric Analysis of the Italian Labour Productivity Crisis." Cambridge Journal of Economics 34(3): 525546.

Malcomson, J.M. 1997. "Contracts, Hold-Up, and Labor Markets." Journal of Economic Literature 35(4): 1916-1957.

Malerba, F. 2002. "Sectoral Systems of Innovation and Production." Research Policy 31(2): 247-264.

Malerba, F. 2006. Sectoral Systems: How and Why Innovation Differs across Sectors. Oxford University Press.

Malerba, F., and Orsenigo, L. 1997. "Technological Regimes and Sectoral Patterns of Innovative Activities." Industrial and Corporate Change 6(1): 83-118.

Marquetti, A. 2004. "Do rising real wages increase the rate of labor-saving technical change? Some econometric evidence." Metroeconomica 55(4): 432-441.

Mensch, G. 1979. Stalemate in technology. Ballinger: Cambridge. 
Michie, J., and Sheehan, M. 1999. "Innovative Investment: Evidence from the UK' s 1990 Workplace Industrial Relations Survey (WIRS)." Industrial and Corporate Change 8(2): 211-234.

Michie, J., and Sheehan, M. 2003. "Labour market deregulation, 'flexibility' and innovation." Cambridge Journal of Economics 27(1): 123-143.

Milberg, W., and Winkler, D. 2013. Outsourcing Economics. Cambridge: Cambridge University Press.

Nelson, R., and Winter, S. 1982. An Evolutionary Theory of Economic Change. Cambridge: Harvard University Press.

Nickell, S., and Layard, R. 1999. "Labor market institutions and economic performance." In Ashenfelter, O., and Card, D. (eds) Handbook of Labor Economics, Vol. 3, Part C, 30293084. North Holland: Elsevier.

Nielen, S. 2016. "Temporary Agency Work and Firm Competitiveness: Evidence from German Manufacturing Firms.” Contributions to Management Science 53(3): 41-67.

OECD. 1994. OECD Jobs Study: Facts, Analysis, Strategy. Paris: OECD Publication Centre.

OECD. 2015. "Non-Standard Work, Job Polarisation and Inequality." In OECD (ed) In It Together: Why Less Inequality Benefits All, 135-208. Paris: OECD Publishing.

Ortega, B., and Marchante, A.J. 2010. "Temporary Contracts and Labour Productivity in Spain: A Sectoral Analysis.” Journal of Productivity Analysis 34(3): 199-212.

Pavitt, K. 1984. "Sectoral Patterns of Technical Change: Towards a Taxonomy and a Theory." Research Policy 13(6): 343-373.

Peneder, M. 2010. "Technological Regimes and the Variety of Innovation Behaviour: Creating Integrated Taxonomies of Firms and Sectors." Research Policy 39: 323-334.

Pianta, M. 2001. "Innovation, Demand and Employment." In Petit, P., and Soete, L. (eds) Technology and the future of European Employment, 142-165. Cheltenham: Elgar.

Pianta, M., Coveri, A., and Reljic, J. 2020. "The Sectoral Innovation Database. Methodological Notes." WP-EMS 2020/01. University of Urbino.

Pieroni, L., and Pompei, F. 2008. "Evaluating Innovation and Labour Market Relationships: The Case of Italy." Cambridge Journal of Economics 32(2): 325-347.

Portugal, P. and Varejão, J. 2009. "Why Do Firms Use Fixed-Term Contracts?" IZA Discussion Paper 4380.

Pöschl, J., Foster-McGregor, N., and Stehrer, R. 2016. "International R\&D Spillovers and Business Service Innovation.” The World Economy 39(12): 2025-2045.

Reljic, J., Evangelista, R., and Pianta, M. 2019. "Digital Technologies, Employment and Skills." LEM Papers Series 36.

Saint-Paul, G. 1997. "Is Labour Rigidity Harming Europe's Competitiveness? The Effect of Job Protection on the Pattern of Trade and Welfare." European Economic Review 41(35): 499-506.

Saint-Paul, G. 2002. "Employment Protection, International Specialization, and Innovation." European Economic Review 46(2): 375-395. 
Scarpetta, S., and Tressel, T. 2004. "Boosting Productivity via Innovation and Adoption of New Technologies: Any Role for Labor Market Institutions?" Policy Research Working Paper Series 3273. The World Bank.

Schumpeter, J.A. 1934. The theory of economic development: an inquiry into profits, capital, credit, interest and the business cycle. Cambridge: Harvard University Press.

Schumpeter, J.A. 1942. Capitalism, socialism and democracy. New York: Harper.

Shapiro, C., and Stiglitz, J.E. 1984. "Equilibrium Unemployment as a Worker Discipline Device." American Economic Review 74: 433-44.

Storm, S., and Naastepad, C.W.M. 2009. "Labor Market Regulation and Productivity Growth: Evidence for Twenty OECD Countries (1984-2004).” Industrial Relations 48(4): 629654.

Storm, S., and Naastepad, C.W.M. 2017. "Bhaduri-Marglin Meet Kaldor-Marx: Wages, Productivity and Investment." Review of Keynesian Economics 5(1): 4-24.

Svensson, S. 2011. "Flexible Working Conditions and Decreasing Levels of Trust." Employee Relations 34(2): 126-137.

Sylos Labini, P. 1984. The Forces of Economic Growth and Decline, Cambridge: MIT Press.

Tajoli, L., and Felice, G. 2018. "Global Value Chains Participation and Knowledge Spillovers in Developed and Developing Countries: An Empirical Investigation." The European Journal of Development Research 30(3): 505-532.

Timmer, M.P., Dietzenbacher, E., Los, B., Stehrer, R., and de Vries, G.J. 2015. “An Illustrated User Guide to the World Input-Output Database: The Case of Global Automotive Production." Review of International Economics 23(3): 575-605.

Van Reenen, J. 1996. "The Creation and Capture of Rents: Wages and Innovation in a Panel of U.K. Companies.” The Quarterly Journal of Economics 111(1): 195-226.

Vergeer, R., and Kleinknecht, A. 2010. "The impact of labor market deregulation on productivity: a panel data analysis of 19 OECD countries (1960-2004)." Journal of Post Keynesian Economics 33(2): 371-408.

Vergeer, R., Dhondt, S., Kleinknecht, A., and Kraan, K. 2015. "Will 'Structural Reforms' of Labour Markets Reduce Productivity Growth? A Firm-Level Investigation.” European Journal of Economics and Economic Policies: Intervention 12(3): 300-317.

Wachsen, E., and Blind, K. 2016. "More Labour Market Flexibility for More Innovation? Evidence from Employer-Employee Linked Micro Data.” Research Policy 45(5): 941950.

Wooldridge, J.M. 2002. Econometric Analysis of Cross Section and Panel Data. Cambridge: MIT Press.

Zhou, H., Dekker, R., and Kleinknecht, A. 2011. "Flexible Labor and Innovation Performance: Evidence from Longitudinal Firm-Level Data." Industrial and Corporate Change 20(3): 941-968. 


\section{Appendix}

Table A1. Effects of labour flexibility on innovation and productivity: selected empirical studies

\begin{tabular}{lllll}
\hline Data & Authors & $\begin{array}{l}\text { Country and } \\
\text { time coverage }\end{array}$ & $\begin{array}{l}\text { Dependent } \\
\text { variable }\end{array}$ & Results
\end{tabular}

\begin{tabular}{|c|c|c|c|c|c|}
\hline $\begin{array}{l}\text { Industry- } \\
\text { level }\end{array}$ & $\begin{array}{l}\text { Bassanini and } \\
\text { Ernst (2002) }\end{array}$ & $\begin{array}{l}\text { Multiple } \\
\text { countries (18 } \\
\text { OECD } \\
\text { countries); } \\
\text { 1993-1997 }\end{array}$ & $\mathrm{R} \& \mathrm{D}$ intensity & $\begin{array}{l}\text { (-) EPL in low-tech } \\
\text { industries and in } \\
\text { decentralised countries } \\
\text { (+) EPL in high-tech } \\
\text { industries and countries } \\
\text { with coordinated } \\
\text { industrial relations setting }\end{array}$ & $\begin{array}{l}\text { Cross-section; } \\
\text { OLS, WLS }\end{array}$ \\
\hline $\begin{array}{l}\text { Industry- } \\
\text { level }\end{array}$ & $\begin{array}{l}\text { Scarpetta and } \\
\text { Tressel } \\
(2004)\end{array}$ & $\begin{array}{l}\text { Multiple } \\
\text { countries; } \\
\text { 1984-1998 }\end{array}$ & $\begin{array}{l}\text { Multifactor } \\
\text { productivity }\end{array}$ & $\begin{array}{l}\text { (-) EPL*medium } \\
\text { corporatism (sectoral } \\
\text { wage bargaining is } \\
\text { predominant without } \\
\text { coordination) }\end{array}$ & $\begin{array}{l}\text { Panel; POLS } \\
\text { with country, } \\
\text { year, industry } \\
\text { fixed effects }\end{array}$ \\
\hline $\begin{array}{l}\text { Industry- } \\
\text { level }\end{array}$ & $\begin{array}{l}\text { Auer et al. } \\
(2005)\end{array}$ & $\begin{array}{l}\text { Multiple } \\
\text { countries; } \\
\text { 1992-2002 }\end{array}$ & $\begin{array}{l}\text { Labour } \\
\text { productivity }\end{array}$ & $\begin{array}{l}(+) \text { job-tenure } \\
\text { non-monotonic }\end{array}$ & $\begin{array}{l}\text { Panel; POLS } \\
\text { with country } \\
\text { and industry } \\
\text { fixed effects }\end{array}$ \\
\hline $\begin{array}{l}\text { Industry- } \\
\text { level, Italian } \\
\text { regions }\end{array}$ & $\begin{array}{l}\text { Pieroni and } \\
\text { Pompei } \\
(2008)\end{array}$ & $\begin{array}{l}\text { Italy; } 10 \\
\text { manuf. sectors, } \\
20 \text { regions; } \\
1990-1996\end{array}$ & $\begin{array}{l}\text { Patent per } \\
\text { capita }\end{array}$ & $\begin{array}{l}\text { (-) Job turnover in } \\
\text { Nothern Italy } \\
\text { (+) Wages of blue and } \\
\text { white collars }\end{array}$ & Panel; GMM \\
\hline $\begin{array}{l}\text { Industry- } \\
\text { level }\end{array}$ & $\begin{array}{l}\text { Bassanini et } \\
\text { al. (2009) }\end{array}$ & $\begin{array}{l}11 \text { OECD } \\
\text { countries, } 19 \\
\text { sectors; } \\
1982-2003\end{array}$ & TFP growth & $\begin{array}{l}\text { (-) EPL for permanent } \\
\text { contracts } \\
\text { (no effect, +) EPL for TE }\end{array}$ & OLS, WLS \\
\hline $\begin{array}{l}\text { Industry- } \\
\text { level }\end{array}$ & $\begin{array}{l}\text { Damiani and } \\
\text { Pompei } \\
(2010)\end{array}$ & $\begin{array}{l}\text { Multiple } \\
\text { countries; } \\
\text { 1995-2005 }\end{array}$ & $\begin{array}{l}\text { Multifactor } \\
\text { productivity }\end{array}$ & $\begin{array}{l}\text { (-) FT } \\
\text { (no effect) PT }\end{array}$ & $\begin{array}{l}\text { Panel; POLS, } \\
\text { Difference- } \\
\text { and-difference }\end{array}$ \\
\hline $\begin{array}{l}\text { Industry- } \\
\text { level } \\
\text { (Spanish } \\
\text { regions) }\end{array}$ & $\begin{array}{l}\text { Ortega and } \\
\text { Marchante } \\
(2010)\end{array}$ & $\begin{array}{l}\text { Spain; 1987- } \\
2000\end{array}$ & $\begin{array}{l}\text { Labour } \\
\text { productivity }\end{array}$ & (-) TE & $\begin{array}{l}\text { Panel; OLS, } \\
\text { FD }\end{array}$ \\
\hline $\begin{array}{l}\text { Industry- } \\
\text { level }\end{array}$ & Lisi (2013) & $\begin{array}{l}\text { Multiple } \\
\text { countries*; } \\
1992-2005\end{array}$ & $\begin{array}{l}\text { Labour } \\
\text { productivity }\end{array}$ & (-) TE & $\begin{array}{l}\text { Panel; POLS, } \\
\text { FE, FD; IV- } \\
\text { FE; IV-FD }\end{array}$ \\
\hline $\begin{array}{l}\text { Industry- } \\
\text { level }\end{array}$ & $\begin{array}{l}\text { Damiani et al. } \\
\text { (2016) }\end{array}$ & $\begin{array}{l}\text { Multiple } \\
\text { countries, } 10 \\
\text { sectors; 1995- } \\
2007\end{array}$ & $\begin{array}{l}\text { TFP growth, } \\
\text { training }\end{array}$ & $\begin{array}{l}\text { (+) EPL for temporary } \\
\text { contracts }\end{array}$ & Panel; FGLS \\
\hline
\end{tabular}




\begin{tabular}{|c|c|c|c|c|c|}
\hline $\begin{array}{l}\text { Industry- } \\
\text { level }\end{array}$ & $\begin{array}{l}\text { Lisi and Malo } \\
\text { (2017) }\end{array}$ & $\begin{array}{l}\text { Multiple } \\
\text { countries*, } 10 \\
\text { sectors; 1992- } \\
2007\end{array}$ & $\begin{array}{l}\text { Labour } \\
\text { productivity }\end{array}$ & $\begin{array}{l}\text { (-) TE } \\
\text { (-) TE*skilled sectors }\end{array}$ & $\begin{array}{l}\text { Panel; POLS, } \\
\text { FE, IV }\end{array}$ \\
\hline $\begin{array}{l}\text { Industry- } \\
\text { level }\end{array}$ & $\begin{array}{l}\text { Cetrulo et al. } \\
(2019)\end{array}$ & $\begin{array}{l}\text { Multiple } \\
\text { countries } \\
\text { (France, } \\
\text { Germany, } \\
\text { Italy, the } \\
\text { Netherlands } \\
\text { and Spain); } \\
\text { 1998-2012 }\end{array}$ & $\begin{array}{l}\text { Share of } \\
\text { product } \\
\text { innovators, } \\
\text { total } \\
\text { innovators }\end{array}$ & $\begin{array}{l}\text { (-) TE } \\
\text { (-) TE*High } \\
\text { cumulativeness (Pender) } \\
\text { (+) EPL }\end{array}$ & Panel; WLS \\
\hline \multicolumn{6}{|c|}{ Micro-level studies } \\
\hline Firm-level & $\begin{array}{l}\text { Michie and } \\
\text { Sheehan } \\
\text { (1999) }\end{array}$ & $\begin{array}{l}\text { UK (Trading } \\
\text { sector only); } \\
1990\end{array}$ & $\begin{array}{l}\text { Investment in } \\
\mathrm{R} \& \mathrm{D}\end{array}$ & $\begin{array}{l}\text { (-) TE, seasonal, fixed } \\
\text { (-) PT } \\
\text { (+) trade-unions }\end{array}$ & Cross-section; \\
\hline Firm-level & $\begin{array}{l}\text { Michie and } \\
\text { Sheehan } \\
(2003)\end{array}$ & $\begin{array}{l}\text { UK; } 1997- \\
1999\end{array}$ & $\begin{array}{l}\text { Innovation (at } \\
\text { least one, } \\
\text { product and/or } \\
\text { process) }\end{array}$ & $\begin{array}{l}\text { (+) FE } \\
\text { (-) PT only for process } \\
\text { innovation } \\
\text { (-) TE for process \& total } \\
\text { innovation } \\
\text { (-) FT for process \& total } \\
\text { innovation } \\
\text { (-) job turnover } \\
\text { (+) Unions }(1 \text { if }>50 \%)\end{array}$ & $\begin{array}{l}\text { Cross-section; } \\
\text { Probit }\end{array}$ \\
\hline Firm-level & $\begin{array}{l}\text { Arvanitis } \\
(2005)\end{array}$ & $\begin{array}{l}\text { Switzerland; } \\
1998-2000 \\
\text { (cross-section) }\end{array}$ & $\begin{array}{l}\text { Labour } \\
\text { productivity } \\
\text { Innovation }\end{array}$ & $\begin{array}{l}\text { (-) PT on productivity } \\
\text { (no effect) TE on } \\
\text { productivity; } \\
\text { (+) functional flex on } \\
\text { productivity } \\
\text { (+) TE for product innov } \\
\text { (-) PT on innovation } \\
\text { (+) TE on innovation }\end{array}$ & $\begin{array}{l}\text { Cross-section; } \\
\text { OLS, Probit }\end{array}$ \\
\hline $\begin{array}{l}\text { Employer- } \\
\text { employee }\end{array}$ & $\begin{array}{l}\text { Kleinknecht } \\
\text { et al. (2006) }\end{array}$ & $\begin{array}{l}\text { Netherlands; } \\
\text { 1992-1994 }\end{array}$ & $\begin{array}{l}\text { Gross hourly } \\
\text { wages, } \\
\text { Sales growth }\end{array}$ & (-) TE on wages & \\
\hline Firm-level & $\begin{array}{l}\text { Boeri and } \\
\text { Garibaldi } \\
(2007)\end{array}$ & $\begin{array}{l}\text { Italy; 1995- } \\
2000\end{array}$ & $\begin{array}{l}\text { Labour } \\
\text { productivity; } \\
\text { Employment }\end{array}$ & $\begin{array}{l}\text { (-) TE (both in levels and } \\
\text { first difference) } \\
\text { (+) reducing EPL (in } \\
\text { short-run) }\end{array}$ & Panel; Probit \\
\hline Firm-level & $\begin{array}{l}\text { Lucidi and } \\
\text { Kleinknecht } \\
(2010)\end{array}$ & $\begin{array}{l}\text { Italy } \\
\text { (Manufacturin } \\
\text { g only); 2001- } \\
2003\end{array}$ & $\begin{array}{l}\text { Labour } \\
\text { productivity }\end{array}$ & $\begin{array}{l}(-) \text { TE } \\
(-) \text { job turnover } \\
(+) \text { labour cost (wages): } \\
\text { past wage growth has a } \\
\text { positive effect on } \\
\text { productivity }\end{array}$ & $\begin{array}{l}\text { Cross-section; } \\
\text { OLS }\end{array}$ \\
\hline
\end{tabular}




\begin{tabular}{|c|c|c|c|c|c|}
\hline Firm-level & $\begin{array}{l}\text { Altuzarra and } \\
\text { Serrano } \\
(2010)\end{array}$ & $\begin{array}{l}\text { Spain } \\
\text { (Manufacturin } \\
\text { g only), Spain, } \\
2000-2002\end{array}$ & $\begin{array}{l}\text { Product } \\
\text { innovation; } \\
\text { process } \\
\text { innovation; } \\
\text { R\&D activity }\end{array}$ & $\begin{array}{l}\text { (no effect) share of fixed- } \\
\text { term contracts (continuous } \\
\text { var) } \\
\text { (+) TE with innovation } \\
\text { performance and R\&D up } \\
\text { to a threshold (mean), } \\
\text { beyond which propensity } \\
\text { to innovate is not } \\
\text { significantly different. }\end{array}$ & $\begin{array}{l}\text { Panel; RE } \\
\text { Logit }\end{array}$ \\
\hline Firm-level & $\begin{array}{l}\text { Zhou et al. } \\
\text { (2011) }\end{array}$ & $\begin{array}{l}\text { Netherlands; } \\
\text { 1993-2001 }\end{array}$ & $\begin{array}{l}\text { No innovation; } \\
\text { incremental } \\
\text { innovation; } \\
\text { radical } \\
\text { innovation; } \\
\text { sales of new } \\
\text { products } \\
\text { and/or } \\
\text { services. }\end{array}$ & $\begin{array}{l}\text { (+) Quality of human } \\
\text { capital - Univ.graduates } \\
\text { (+) R\&D Intensity } \\
\text { (+) Size at } 10 \% \\
\text { (+) Age } \\
\text { (no effect, sometimes +) } \\
\text { TE } \\
\text { (+) labour turnover } \\
\text { (+) Functional flexibility }\end{array}$ & $\begin{array}{l}\text { Panel; OLS, } \\
\text { Tobit, } \\
\text { Heckman, } \\
\text { Heckman- } \\
\text { Tobit }\end{array}$ \\
\hline Firm-level & $\begin{array}{l}\text { Cappellari et } \\
\text { al. }(2012)\end{array}$ & $\begin{array}{l}\text { Italy; 2004- } \\
2007\end{array}$ & Productivity & $\begin{array}{l}\text { (+) apprenticeship } \\
(-) \text { fixed-term contract }\end{array}$ & $\begin{array}{l}\text { Panel; Diff- } \\
\text { and-diff }\end{array}$ \\
\hline $\begin{array}{l}\text { Establishmen } \\
\text { t-level }\end{array}$ & $\begin{array}{l}\text { Hirsch, B. } \\
\text { and Mueller, } \\
\text { T. (2012) }\end{array}$ & $\begin{array}{l}\text { Germany; } \\
\text { 2003-2009 }\end{array}$ & Productivity & $\begin{array}{l}\text { (+) TAW } \\
\text { (-) TAW2 } \\
\text { (-) \% Female } \\
\text { (+) \% skilled workers } \\
\text { (-) } \% \text { apprenticeships } \\
\text { (-) part-time }\end{array}$ & $\begin{array}{l}\text { Panel; GMM, } \\
\text { FE }\end{array}$ \\
\hline Firm-level & $\begin{array}{l}\text { Giannetti and } \\
\text { Madia (2013) }\end{array}$ & $\begin{array}{l}\text { Italy } \\
\text { (Manufacturin } \\
\text { g only); 1998- } \\
2003 \text { (two } \\
\text { waves, 1998- } \\
2000 ; 2001- \\
2003) ;\end{array}$ & $\begin{array}{l}\text { Innovative } \\
\text { ability (new } \\
\text { products in } \\
\text { sales) }\end{array}$ & $\begin{array}{l}\text { (+) PT, TE } \\
\text { (+) functional flexibility } \\
\text { (-) Labour turnover*High- } \\
\text { tech }\end{array}$ & $\begin{array}{l}\text { Both cross- } \\
\text { section and } \\
\text { panel } \\
\text { estimates: } \\
\text { Heckman } \\
\text { panel } \\
\text { estimator; } \\
\text { Generalized } \\
\text { (type II) Tobit } \\
\text { model }\end{array}$ \\
\hline $\begin{array}{l}\text { Employer- } \\
\text { employee }\end{array}$ & $\begin{array}{l}\text { Bryson } \\
(2013)\end{array}$ & $\begin{array}{l}\text { UK; } 1998 \text { and } \\
2004\end{array}$ & $\begin{array}{l}\text { Financial } \\
\text { performance } \\
\text { ( } 1 \text { if it is better } \\
\text { than industry } \\
\text { average; } \\
\text { otherwise } 0) \\
\text { Labour } \\
\text { productivity ( } 1 \\
\text { if it is better } \\
\text { than ind. } \\
\text { average) }\end{array}$ & $\begin{array}{l}\text { (+) TAW on firms' } \\
\text { performance } \\
\text { (no effect) TAW on } \\
\text { labour productivity }\end{array}$ & Panel; Probit \\
\hline
\end{tabular}




\begin{tabular}{|c|c|c|c|c|c|}
\hline Firm-level & $\begin{array}{l}\text { Kleinknecht } \\
\text { et al. (2014) }\end{array}$ & $\begin{array}{l}\text { Netherlands; } \\
\text { CIS (1998- } \\
\text { 2008) and } \\
\text { Enterprise } \\
\text { survey data } \\
\text { OSA-SCP } \\
(1987-88)\end{array}$ & $\begin{array}{l}\text { Investment in } \\
\text { R\&D (total, } \\
\text { permanent, } \\
\text { occasional) }\end{array}$ & $\begin{array}{l}\text { (no effect) agency work } \\
(-) \text { TE in almost all } \\
\text { specifications } \\
\text { (-) TE*Herfindahl } \\
\text { Hirchman index } \\
\text { sample split: } \\
\text { (-) TE in Schumpeter } \\
\text { mark II } \\
\text { (no effect) TE in } \\
\text { Schumpeter mark I }\end{array}$ & $\begin{array}{l}\text { Cross-section; } \\
\text { Logit }\end{array}$ \\
\hline Firm-level & $\begin{array}{l}\text { Franceschi } \\
\text { and Mariani } \\
(2016)\end{array}$ & $\begin{array}{l}\text { Italy } \\
\text { (Manufacturin } \\
\text { g only); 2001- } \\
2009\end{array}$ & $\begin{array}{l}\text { Patent } \\
\text { applications }\end{array}$ & $\begin{array}{l}\text { (-) TE } \\
\text { (-) TE in large firms, and } \\
\text { (no effect) among others }\end{array}$ & $\begin{array}{l}\text { Cross-section; } \\
\text { OLS, Poisson, } \\
2 \text { SLS }\end{array}$ \\
\hline $\begin{array}{l}\text { Employer- } \\
\text { employee }\end{array}$ & $\begin{array}{l}\text { Wachsen and } \\
\text { Blind (2016) }\end{array}$ & $\begin{array}{l}\text { Netherlands; } \\
\text { 1998-2008 }\end{array}$ & $\begin{array}{l}\text { Product } \\
\text { innovation; } \\
\text { process } \\
\text { innovation }\end{array}$ & $\begin{array}{l}\text { (-) Job turnover in the } \\
\text { routinised model. } \\
\text { (-) Flexible wage setting } \\
\text { on process innovation, but } \\
\text { not on product innovation. } \\
\text { (+) Median wage } \\
\text { (-) Wage differentials }\end{array}$ & $\begin{array}{l}\text { (hire specialist } \\
\text { on temp basis } \\
\text { for R\&D } \\
\text { process) }\end{array}$ \\
\hline Firm-level & Nielen (2016) & $\begin{array}{l}\text { Germany } \\
\text { (Manufacturin } \\
\text { g only); panel } \\
\text { data; }\end{array}$ & $\begin{array}{l}\text { Unit labour } \\
\text { cost }\end{array}$ & $\begin{array}{l}\text { U shaped relationship } \\
\text { (-) TAW } \\
\text { (+) TAW2 }\end{array}$ & Panel; GMM \\
\hline Firm-level & $\begin{array}{l}\text { Devicienti et } \\
\text { al. }(2018)\end{array}$ & $\begin{array}{l}\text { Italy; 2000- } \\
2010\end{array}$ & $\begin{array}{l}\text { TFP } \\
\text { productivity }\end{array}$ & $\begin{array}{l}\text { (-) PT } \\
\text { (-) PT horizontal \& mixed } \\
\text { (no effect) PT vertical }\end{array}$ & $\begin{array}{l}\text { Panel; OLS, } \\
\text { FE, IV }\end{array}$ \\
\hline Firm-level & $\begin{array}{l}\text { Grinza and } \\
\text { Quatraro } \\
(2019)\end{array}$ & $\begin{array}{l}\text { Italy (Veneto } \\
\text { region); 1995- } \\
2001\end{array}$ & $\begin{array}{l}\text { Patent } \\
\text { applications }\end{array}$ & $\begin{array}{l}\text { (-) Excessive job turnover } \\
\text { They also test the extent } \\
\text { of job turnover finding } \\
\text { that it is negative for all } \\
<10 \% ;>10 ;<30 \% ;>30 \% \\
\text { (no effect) TE and PT }\end{array}$ & $\begin{array}{l}\text { Panel; } \\
\text { Negative } \\
\text { binomial } \\
\text { regressions; } \\
\text { IV }\end{array}$ \\
\hline Firm-level & $\begin{array}{l}\text { Hoxha and } \\
\text { Kleinknecht } \\
(2020)\end{array}$ & $\begin{array}{l}\text { Germany; } \\
\text { 2007-2015 }\end{array}$ & $\begin{array}{l}\text { R\&D ( } 1 \text { if it } \\
\text { does R\&D; } 0 \\
\text { otherwise); } \\
\text { both } R \& D \text { and } \\
\text { product } \\
\text { innovation } \\
(0 ; 1)\end{array}$ & $\begin{array}{l}\text { (-) \% of terminated } \\
\text { contracts in total sample } \\
\text { (-) \% of terminated } \\
\text { contracts in high } \\
\text { 'cumulativeness of } \\
\text { knowledge' industries } \\
\text { (Peneder classification) } \\
\text { (no effect) \% of } \\
\text { terminated contracts in } \\
\text { low 'cumulativeness of } \\
\text { knowledge' industries } \\
\text { (Peneder classification) }\end{array}$ & $\begin{array}{l}\text { RE Panel } \\
\text { Probit model; } \\
\text { Pooled Probit } \\
\text { model }\end{array}$ \\
\hline
\end{tabular}

Source: authors' elaboration.

Note: EPL=Employment Protection Legislation index; TE=Temporary Employment; TAW=Temporary Agency Work; PT=Part-Time; FT=Fixed-Term employment.

*Austria, Belgium, Denmark, Finland, France, Germany, Ireland, Italy, the Netherlands, Portugal, Spain, Sweden and the United Kingdom. 
Table A2. Description of variables and data sources

\begin{tabular}{|c|c|}
\hline Variable & Description \\
\hline Non-standard workers & $\begin{array}{l}\text { Share of workers who have a non-standard type of employment } \\
\text { contract (Permanent }+ \text { Part-time; Temporary }+ \text { Full-time; } \\
\text { Temporary }+ \text { Part-time) over the total number of employees. } \\
\text { Source: EU LFS }\end{array}$ \\
\hline Product innovation & $\begin{array}{l}\text { Share of firms that significantly improved their goods and services } \\
\text { in the observed period, regardless of any other type of innovation. } \\
\text { Source: Community Innovation Survey (Eurostat). }\end{array}$ \\
\hline Process innovation & $\begin{array}{l}\text { Share of firms that implemented a new or significantly improved } \\
\text { production or delivery method in the observed period, regardless } \\
\text { of any other type of innovation. Source: Community Innovation } \\
\text { Survey (Eurostat). }\end{array}$ \\
\hline Size & $\begin{array}{l}\text { Average firm size computed as the ratio between the total number } \\
\text { of employees over the number of firms in the sector. Source: } \\
\text { Community Innovation Survey (Eurostat). }\end{array}$ \\
\hline Expenditure in internal R\&D & $\begin{array}{l}\text { In-house research and development expenditure per employee. } \\
\text { Source: Community Innovation Survey (Eurostat), deflated by } \\
\text { aggregate value-added deflator sourced from OECD-STAN. }\end{array}$ \\
\hline
\end{tabular}

$1996-2016$ contract (Permanent + Part-time; Temporary + Full-time; Temporary + Part-time) over the total number of employees. urce: EU LFS in the observed period, regardless of any other type of innovation. Share of firms that implemented a new or significantly improved aggregate value-added deflator sourced from OECD-STAN.

Expenditure in machinery

Expenditure in machinery and equipment per employee. Source: Community Innovation Survey (Eurostat), deflated by aggregate value-added deflator sourced from OECD-STAN.

Value added is expressed as the compound average annual growth

Value added rate deflated by country-industry specific value-added deflators. Source: OECD-STAN.

Average labour compensation per employee is expressed as the

Average labour compensation compound average annual growth rate deflated by the aggregate value-added deflator at country-level. Source: OECD-STAN.

Computed as the share of intermediate inputs imported from

High-tech intermediate inputs foreign high-tech industries (namely Science Based and Specialised Suppliers sectors) over industries' total intermediate $1996-2016$ inputs used for production. Source: WIOD.

Computed as the share of employees holding at least a bachelor's

University graduates degree (ISCED 6, ISCED 7, ISCED 8) over the total number of employees. Source: EU LFS.

Computed as the share of employees in occupations ISCO1 (Managers, senior officials and legislators), ISCO2

Managers (Professionals) and ISCO3 (Technicians and associate professionals) over the total number of employees. Source: EU LFS.

Computed as the share of employees in occupations ISCO8 (Plant and machine operators and assemblers) and ISCO9 (Elementary occupations) over the total number of employees. Source: EU LFS.

Source: authors' elaboration. 
Table A3. Summary statistics of variables

\begin{tabular}{lcccc}
\hline Variable & Mean & Std.Dev. & Min & Max \\
\hline Share of non-standard workers & 21.48 & 15.26 & 0.03 & 81.8 \\
Share of product innovators & 35.3 & 18.3 & 2.53 & 90.52 \\
Share of process innovators & 30.19 & 13.43 & 0.13 & 88.78 \\
Internal R\&D expenditure & 2.73 & 5.13 & 0.00 & 34.42 \\
Expenditure in machinery & 1.44 & 1.73 & 0.00 & 12.43 \\
High-tech intermediate inputs & 0.59 & 1.98 & -8.19 & 14.27 \\
Size & 0.21 & 0.31 & 0.01 & 2.41 \\
Rate of change of value added & 1.34 & 4.2 & -16.61 & 28.35 \\
Rate of change of average labour cost & 0.96 & 2.1 & -7.92 & 12.8 \\
Share of managers & 39.76 & 21.28 & 3.05 & 95.9 \\
Share of manual workers & 24.43 & 16.42 & 0.18 & 78.69 \\
Share of university graduates & 25.21 & 17.07 & 0.05 & 84.73 \\
Share of workers with low education & 26.24 & 15.29 & 0.00 & 78.85 \\
\hline
\end{tabular}

Source: authors' elaboration on SID database.

Table A4. Weighted mean values of variables in low- and high-tech industries, 1994-2016

\begin{tabular}{lcc}
\hline & Low-tech & High-tech \\
\hline Share of non-standard workers (NSW) & 29.48 & 19.67 \\
Share of product innovators & 26.13 & 44.52 \\
Share of process innovators & 24.51 & 32.27 \\
Internal R\&D expenditure & 1.04 & 4.18 \\
Expenditure in machinery & 1.07 & 1.27 \\
Size & 0.23 & 0.21 \\
Rate of change of value added & 1.35 & 2.39 \\
Rate of change of average labour cost & 0.84 & 1.15 \\
Share of managers & 26.95 & 53.63 \\
Share of manual workers & 24.00 & 16.86 \\
Share of university graduates & 17.16 & 36.89 \\
Share of workers with low education & 29.26 & 17.53 \\
\hline
\end{tabular}

Source: authors' elaboration on SID database. 
Table A5. List of sectors

\begin{tabular}{|c|c|c|c|}
\hline Sectors (NACE Rev.2 Classification) & $\begin{array}{l}\text { NACE } \\
\text { codes }\end{array}$ & $\begin{array}{l}\text { Revised } \\
\text { Pavitt } \\
\text { class. }\end{array}$ & $\begin{array}{l}\text { High- } \\
\text { tech/Low- } \\
\text { tech }\end{array}$ \\
\hline Manufacture of food products, beverages and tobacco products & $\mathrm{C} 10-\mathrm{C} 12$ & SD & Low-tech \\
\hline Manufacture of textiles, wearing apparel and leather products & $\mathrm{C} 13-\mathrm{C} 15$ & SD & Low-tech \\
\hline Manufacture of wood and of products of wood and cork, except furniture & $\mathrm{C} 16$ & SD & Low-tech \\
\hline Manufacture of paper and paper products & $\mathrm{C} 17$ & SI & Low-tech \\
\hline Printing and reproduction of recorded media & $\mathrm{C} 18$ & SI & Low-tech \\
\hline Manufacture of chemicals and chemical products & $\mathrm{C} 20$ & SB & High-tech \\
\hline Manufacture of basic pharmaceutical products and pharmaceutical preparations & $\mathrm{C} 21$ & SB & High-tech \\
\hline Manufacture of rubber and plastic products & $\mathrm{C} 22$ & SI & Low-tech \\
\hline Manufacture of other non-metallic mineral products & $\mathrm{C} 23$ & SI & Low-tech \\
\hline Manufacture of basic metals & $\mathrm{C} 24$ & SI & Low-tech \\
\hline Manufacture of fabricated metal products, except machinery and equipment & $\mathrm{C} 25$ & $\mathrm{SD}$ & Low-tech \\
\hline Manufacture of computer, electronic and optical products & $\mathrm{C} 26$ & SB & High-tech \\
\hline Manufacture of electrical equipment & $\mathrm{C} 27$ & SS & High-tech \\
\hline Manufacture of machinery and equipment n.e.c. & $\mathrm{C} 28$ & SS & High-tech \\
\hline Manufacture of motor vehicles, trailers and semi-trailers & $\mathrm{C} 29$ & SI & Low-tech \\
\hline Manufacture of other transport equipment & $\mathrm{C} 30$ & SS & High-tech \\
\hline Manufacture of furniture; other manufacturing & $\mathrm{C} 31-\mathrm{C} 32$ & SD & Low-tech \\
\hline Repair and installation of machinery and equipment & $\mathrm{C} 33$ & SS & High-tech \\
\hline Wholesale and retail trade and repair of motor vehicles and motorcycles & G45 & SD & Low-tech \\
\hline Wholesale trade, except of motor vehicles and motorcycles & G46 & SD & Low-tech \\
\hline Retail trade, except of motor vehicles and motorcycles & G47 & $\mathrm{SD}$ & Low-tech \\
\hline Land transport and transport via pipelines & H49 & SD & Low-tech \\
\hline Water transport & $\mathrm{H} 50$ & $\mathrm{SD}$ & Low-tech \\
\hline Air transport & H51 & SD & Low-tech \\
\hline Warehousing and support activities for transportation & $\mathrm{H} 52$ & SD & Low-tech \\
\hline Postal and courier activities & H53 & $\mathrm{SD}$ & Low-tech \\
\hline Accommodation and food service activities & I55-I56 & SD & Low-tech \\
\hline Publishing activities & $\mathrm{J} 58$ & SI & Low-tech \\
\hline Motion picture, video and television programme production & J59-J60 & SI & Low-tech \\
\hline Telecommunications & $\mathrm{J} 61$ & SB & High-tech \\
\hline Computer programming, consultancy and related activities; information service activities & J62-J63 & SB & High-tech \\
\hline Financial service activities, except insurance and pension funding & K64 & SI & Low-tech \\
\hline Insurance, reinsurance and pension funding, except compulsory social security & K65 & SI & Low-tech \\
\hline Activities auxiliary to financial services and insurance activities & K66 & SI & Low-tech \\
\hline Real estate activities & L68 & SS & High-tech \\
\hline
\end{tabular}


Legal and accounting activities; management consultancy activities

$\begin{array}{lll}\text { M69-M70 } & \text { SS } & \text { High-tech } \\ \text { M71 } & \text { SS } & \text { High-tech } \\ \text { M72 } & \text { SB } & \text { High-tech } \\ \text { M73 } & \text { SS } & \text { High-tech } \\ \text { M74-M75 } & \text { SS } & \text { High-tech } \\ \text { N } & \text { SD } & \text { Low-tech }\end{array}$

Architectural and engineering activities; technical testing and analysis

Scientific research and development

Advertising and market research

Other professional, scientific and technical activities; veterinary activities

Administrative and support service activities

Source: authors' elaboration on SID database.

Table A6. Robustness check: product and process innovation estimates including the share of university graduates

\begin{tabular}{|c|c|c|c|c|}
\hline VARIABLES & $\begin{array}{c}(1) \\
\text { Product } \\
\text { innovation }\end{array}$ & $\begin{array}{c}(2) \\
\text { Product } \\
\text { innovation }\end{array}$ & $\begin{array}{c}(3) \\
\text { Process } \\
\text { innovation }\end{array}$ & $\begin{array}{c}(4) \\
\text { Process } \\
\text { innovation }\end{array}$ \\
\hline Share of NSW, lag & $\begin{array}{c}-0.195 * * * \\
(0.0719)\end{array}$ & $\begin{array}{c}-0.188 * * * \\
(0.0720)\end{array}$ & $\begin{array}{c}-0.154 * * * \\
(0.0473)\end{array}$ & $\begin{array}{c}-0.156^{* * * *} \\
(0.0481)\end{array}$ \\
\hline Internal $R \& D$ expenditure, lag & $\begin{array}{c}0.863 * * * \\
(0.206)\end{array}$ & $\begin{array}{c}0.820 * * * \\
(0.205)\end{array}$ & $\begin{array}{c}0.196 \\
(0.124)\end{array}$ & $\begin{array}{l}0.204 * \\
(0.123)\end{array}$ \\
\hline Expenditure in machinery, lag & $\begin{array}{c}0.282 \\
(0.413)\end{array}$ & $\begin{array}{c}0.398 \\
(0.414)\end{array}$ & $\begin{array}{l}0.578^{*} \\
(0.312)\end{array}$ & $\begin{array}{l}0.553^{*} \\
(0.316)\end{array}$ \\
\hline Size & $\begin{array}{l}5.477 * * \\
(2.539)\end{array}$ & $\begin{array}{l}5.557 * * \\
(2.572)\end{array}$ & $\begin{array}{c}4.229 * * \\
(2.076)\end{array}$ & $\begin{array}{l}4.226 * * \\
(2.060)\end{array}$ \\
\hline$\Delta$ Value-added, lag & $\begin{array}{l}-0.243 \\
(0.176)\end{array}$ & $\begin{array}{l}-0.265 \\
(0.176)\end{array}$ & $\begin{array}{l}-0.239^{*} \\
(0.131)\end{array}$ & $\begin{array}{l}-0.235^{*} \\
(0.131)\end{array}$ \\
\hline$\Delta$ Average labour cost, lag & $\begin{array}{c}0.341 \\
(0.325)\end{array}$ & $\begin{array}{c}0.338 \\
(0.324)\end{array}$ & $\begin{array}{l}0.342 * \\
(0.193)\end{array}$ & $\begin{array}{l}0.345^{*} \\
(0.193)\end{array}$ \\
\hline$\Delta$ High-tech int. inputs, lag & & $\begin{array}{l}0.654^{*} \\
(0.371)\end{array}$ & & $\begin{array}{l}-0.160 \\
(0.232)\end{array}$ \\
\hline Share of university graduates, lag & $\begin{array}{c}0.0526 \\
(0.0540)\end{array}$ & $\begin{array}{c}0.0503 \\
(0.0539)\end{array}$ & $\begin{array}{c}0.0372 \\
(0.0384)\end{array}$ & $\begin{array}{c}0.0370 \\
(0.0386)\end{array}$ \\
\hline Period & YES & YES & YES & YES \\
\hline Country & YES & YES & YES & YES \\
\hline Pavitt & YES & YES & YES & YES \\
\hline Constant & $\begin{array}{c}63.87 * * * \\
(3.661)\end{array}$ & $\begin{array}{c}62.78 * * * \\
(3.744)\end{array}$ & $\begin{array}{c}41.99 * * * \\
(2.640)\end{array}$ & $\begin{array}{c}42.32 * * * \\
(2.698)\end{array}$ \\
\hline $\begin{array}{l}\text { Observations } \\
\text { R-squared }\end{array}$ & $\begin{array}{c}568 \\
0.673\end{array}$ & $\begin{array}{c}565 \\
0.675\end{array}$ & $\begin{array}{c}567 \\
0.626\end{array}$ & $\begin{array}{c}564 \\
0.626\end{array}$ \\
\hline
\end{tabular}

Note: Weighted least squares (WLS) with robust standard errors in brackets and weighted data (weights are sectorand time-specific number of employees). ${ }^{*}$ significant at $10 \%,{ }^{* *}$ significant at $5 \%,{ }^{* * *}$ significant at $1 \%$. 
Table A7. Robustness check: product and process innovation estimates with interaction, including the share of university graduates

\begin{tabular}{|c|c|c|c|c|}
\hline VARIABLES & $\begin{array}{c}(1) \\
\text { Product } \\
\text { innovation }\end{array}$ & $\begin{array}{c}(2) \\
\text { Product } \\
\text { innovation }\end{array}$ & $\begin{array}{c}(3) \\
\text { Process } \\
\text { innovation }\end{array}$ & $\begin{array}{c}(4) \\
\text { Process } \\
\text { innovation }\end{array}$ \\
\hline Share of NSW, lag & $\begin{array}{l}-0.126^{*} \\
(0.0684)\end{array}$ & $\begin{array}{l}-0.118 * \\
(0.0685)\end{array}$ & $\begin{array}{c}-0.140 * * * \\
(0.0489)\end{array}$ & $\begin{array}{c}-0.142 * * * \\
(0.0498)\end{array}$ \\
\hline High-tech*Share of NSW, lag & $\begin{array}{c}-0.420 * * * \\
(0.0997)\end{array}$ & $\begin{array}{c}-0.423 * * * \\
(0.100)\end{array}$ & $\begin{array}{l}-0.0862 \\
(0.0663)\end{array}$ & $\begin{array}{l}-0.0846 \\
(0.0665)\end{array}$ \\
\hline Internal R\&D expenditure, lag & $\begin{array}{c}0.778 * * * \\
(0.206)\end{array}$ & $\begin{array}{c}0.734 * * * \\
(0.205)\end{array}$ & $\begin{array}{c}0.178 \\
(0.125)\end{array}$ & $\begin{array}{c}0.187 \\
(0.124)\end{array}$ \\
\hline Expenditure in machinery, lag & $\begin{array}{c}0.321 \\
(0.406)\end{array}$ & $\begin{array}{c}0.438 \\
(0.407)\end{array}$ & $\begin{array}{c}0.586 * \\
(0.311)\end{array}$ & $\begin{array}{l}0.561 * \\
(0.315)\end{array}$ \\
\hline Size & $\begin{array}{c}5.858 * * \\
(2.380)\end{array}$ & $\begin{array}{c}5.936 * * \\
(2.415)\end{array}$ & $\begin{array}{c}4.307 * * \\
(2.066)\end{array}$ & $\begin{array}{c}4.303 * * \\
(2.050)\end{array}$ \\
\hline$\Delta$ Value-added, lag & $\begin{array}{l}-0.246 \\
(0.168)\end{array}$ & $\begin{array}{l}-0.267 \\
(0.169)\end{array}$ & $\begin{array}{c}-0.240 * \\
(0.130)\end{array}$ & $\begin{array}{c}-0.236^{*} \\
(0.131)\end{array}$ \\
\hline$\Delta$ Average labour cost, lag & $\begin{array}{c}0.377 \\
(0.311)\end{array}$ & $\begin{array}{c}0.373 \\
(0.311)\end{array}$ & $\begin{array}{c}0.350 * \\
(0.192)\end{array}$ & $\begin{array}{c}0.352 * \\
(0.193)\end{array}$ \\
\hline$\Delta$ High-tech int. inputs, lag & & $\begin{array}{l}0.670 * \\
(0.348)\end{array}$ & & $\begin{array}{l}-0.157 \\
(0.230)\end{array}$ \\
\hline Share of university graduates, lag & $\begin{array}{c}0.0723 \\
(0.0522)\end{array}$ & $\begin{array}{c}0.0705 \\
(0.0522)\end{array}$ & $\begin{array}{c}0.0413 \\
(0.0382)\end{array}$ & $\begin{array}{c}0.0410 \\
(0.0383)\end{array}$ \\
\hline High-tech $=1$ & $\begin{array}{c}22.97 * * * \\
(2.881)\end{array}$ & $\begin{array}{c}23.31 * * * \\
(2.905)\end{array}$ & $\begin{array}{c}4.898 * * \\
(2.063)\end{array}$ & $\begin{array}{c}4.843 * * \\
(2.071)\end{array}$ \\
\hline Period & YES & YES & YES & YES \\
\hline Country & YES & YES & YES & YES \\
\hline Pavitt & YES & YES & YES & YES \\
\hline Constant & $\begin{array}{c}44.61 * * * \\
(2.392)\end{array}$ & $\begin{array}{c}43.13 * * * \\
(2.500)\end{array}$ & $\begin{array}{c}37.86^{* * * *} \\
(2.013)\end{array}$ & $\begin{array}{c}38.21 * * * \\
(2.119)\end{array}$ \\
\hline Observations & 568 & 565 & 567 & 564 \\
\hline R-squared & 0.685 & 0.687 & 0.627 & 0.627 \\
\hline
\end{tabular}

Note: Weighted least squares (WLS) with robust standard errors in brackets and weighted data (weights are sectorand time-specific number of employees). ${ }^{*}$ significant at $10 \%,{ }^{* *}$ significant at $5 \%,{ }^{* * *}$ significant at $1 \%$. 


\section{Tables}

Table 1. Share of non-standard workers and product innovation

\begin{tabular}{|c|c|c|c|c|}
\hline VARIABLES & $\begin{array}{c}(1) \\
\text { Product } \\
\text { innovation }\end{array}$ & $\begin{array}{c}(2) \\
\text { Product } \\
\text { innovation }\end{array}$ & $\begin{array}{c}(3) \\
\text { Product } \\
\text { innovation }\end{array}$ & $\begin{array}{c}(4) \\
\text { Product } \\
\text { innovation }\end{array}$ \\
\hline Share of NSW, lag & $\begin{array}{c}-0.204^{* * * *} \\
(0.0687)\end{array}$ & $\begin{array}{c}-0.197 * * * \\
(0.0706)\end{array}$ & $\begin{array}{c}-0.190^{* * * *} \\
(0.0707)\end{array}$ & $\begin{array}{r}-0.228 * * * * \\
(0.0693)\end{array}$ \\
\hline Internal $R \& D$ expenditure, lag & $\begin{array}{c}0.866 * * * \\
(0.207)\end{array}$ & $\begin{array}{c}0.845^{* * *} \\
(0.205)\end{array}$ & $\begin{array}{c}0.802 * * * \\
(0.203)\end{array}$ & $\begin{array}{c}0.809 * * * \\
(0.203)\end{array}$ \\
\hline Expenditure in machinery, lag & $\begin{array}{c}0.220 \\
(0.412)\end{array}$ & $\begin{array}{c}0.226 \\
(0.405)\end{array}$ & $\begin{array}{c}0.347 \\
(0.406)\end{array}$ & $\begin{array}{c}0.489 \\
(0.411)\end{array}$ \\
\hline Size & $\begin{array}{l}5.341 * * \\
(2.453)\end{array}$ & $\begin{array}{l}6.103^{* * *} \\
(2.509)\end{array}$ & $\begin{array}{l}6.154 * * \\
(2.548)\end{array}$ & $\begin{array}{l}4.895^{*} \\
(2.772)\end{array}$ \\
\hline$\Delta$ Value-added, lag & & $\begin{array}{l}-0.232 \\
(0.175)\end{array}$ & $\begin{array}{l}-0.255 \\
(0.176)\end{array}$ & $\begin{array}{l}-0.267 \\
(0.185)\end{array}$ \\
\hline$\Delta$ Average labour cost, lag & & $\begin{array}{c}0.349 \\
(0.324)\end{array}$ & $\begin{array}{c}0.346 \\
(0.323)\end{array}$ & $\begin{array}{c}0.392 \\
(0.359)\end{array}$ \\
\hline$\Delta$ High-tech int. inputs, lag & & & $\begin{array}{l}0.659 * \\
(0.369)\end{array}$ & $\begin{array}{l}0.714 * \\
(0.368)\end{array}$ \\
\hline Share of managers, lag & & & & $\begin{array}{l}-0.0216 \\
(0.0581)\end{array}$ \\
\hline Share of manual workers, lag & & & & $\begin{array}{l}-0.101^{*} \\
(0.0530)\end{array}$ \\
\hline Period & YES & YES & YES & YES \\
\hline Country & YES & YES & YES & YES \\
\hline Pavitt & YES & YES & YES & YES \\
\hline Constant & $\begin{array}{c}65.10 * * * \\
(3.131)\end{array}$ & $\begin{array}{c}65.61 * * * \\
(3.361)\end{array}$ & $\begin{array}{c}64.45 * * * \\
(3.459)\end{array}$ & $\begin{array}{c}66.78 * * * \\
(5.017)\end{array}$ \\
\hline $\begin{array}{l}\text { Observations } \\
\text { R-squared }\end{array}$ & $\begin{array}{c}580 \\
0.670\end{array}$ & $\begin{array}{c}575 \\
0.673\end{array}$ & $\begin{array}{c}572 \\
0.675\end{array}$ & $\begin{array}{c}521 \\
0.681\end{array}$ \\
\hline
\end{tabular}

Note: Weighted least squares (WLS) with robust standard errors in brackets and weighted data (weights are sectorand time-specific number of employees). ${ }^{*}$ significant at $10 \%,{ }^{* *}$ significant at $5 \%,{ }^{* * *}$ significant at $1 \%$. 
Table 2. Share of non-standard workers and process innovation

\begin{tabular}{|c|c|c|c|c|}
\hline VARIABLES & $\begin{array}{c}(1) \\
\text { Process } \\
\text { innovation }\end{array}$ & $\begin{array}{c}(2) \\
\text { Process } \\
\text { innovation }\end{array}$ & $\begin{array}{c}(3) \\
\text { Process } \\
\text { innovation }\end{array}$ & $\begin{array}{c}(4) \\
\text { Process } \\
\text { innovation }\end{array}$ \\
\hline Share of NSW, lag & $\begin{array}{c}-0.164 * * * \\
(0.0459)\end{array}$ & $\begin{array}{c}-0.157 * * * \\
(0.0465)\end{array}$ & $\begin{array}{c}-0.159 * * * \\
(0.0473)\end{array}$ & $\begin{array}{c}-0.208 * * * \\
(0.0444)\end{array}$ \\
\hline Internal R\&D expenditure, lag & $\begin{array}{c}0.195 \\
(0.128)\end{array}$ & $\begin{array}{c}0.182 \\
(0.124)\end{array}$ & $\begin{array}{c}0.190 \\
(0.122)\end{array}$ & $\begin{array}{c}0.132 \\
(0.123)\end{array}$ \\
\hline Expenditure in machinery, lag & $\begin{array}{l}0.542 * \\
(0.311)\end{array}$ & $\begin{array}{l}0.541 * \\
(0.306)\end{array}$ & $\begin{array}{l}0.517 * \\
(0.311)\end{array}$ & $\begin{array}{l}0.517 * \\
(0.313)\end{array}$ \\
\hline Size & $\begin{array}{l}3.967 * \\
(2.209)\end{array}$ & $\begin{array}{l}4.661 * * \\
(2.136)\end{array}$ & $\begin{array}{c}4.658 * * \\
(2.120)\end{array}$ & $\begin{array}{c}4.265 * * \\
(2.048)\end{array}$ \\
\hline$\Delta$ Value-added, lag & & $\begin{array}{l}-0.233^{*} \\
(0.130)\end{array}$ & $\begin{array}{l}-0.229 * \\
(0.131)\end{array}$ & $\begin{array}{l}-0.254 * \\
(0.137)\end{array}$ \\
\hline$\Delta$ Average labour cost, lag & & $\begin{array}{l}0.349 * \\
(0.192)\end{array}$ & $\begin{array}{l}0.352 * \\
(0.192)\end{array}$ & $\begin{array}{l}0.371 * \\
(0.209)\end{array}$ \\
\hline$\Delta$ High-tech int. inputs, lag & & & $\begin{array}{l}-0.157 \\
(0.232)\end{array}$ & $\begin{array}{l}-0.124 \\
(0.229)\end{array}$ \\
\hline Share of managers, lag & & & & $\begin{array}{l}-0.0577 \\
(0.0431)\end{array}$ \\
\hline Share of manual workers, lag & & & & $\begin{array}{c}-0.0869 * * \\
(0.0393)\end{array}$ \\
\hline Period & YES & YES & YES & YES \\
\hline Country & YES & YES & YES & YES \\
\hline Pavitt & YES & YES & YES & YES \\
\hline Constant & $\begin{array}{c}42.67 * * * \\
(2.271)\end{array}$ & $\begin{array}{c}43.26 * * * \\
(2.459)\end{array}$ & $\begin{array}{c}43.57 * * * \\
(2.543)\end{array}$ & $\begin{array}{c}48.51 * * * \\
(3.943)\end{array}$ \\
\hline $\begin{array}{l}\text { Observations } \\
\text { R-squared }\end{array}$ & $\begin{array}{c}579 \\
0.619\end{array}$ & $\begin{array}{c}574 \\
0.625\end{array}$ & $\begin{array}{c}571 \\
0.625\end{array}$ & $\begin{array}{c}520 \\
0.639\end{array}$ \\
\hline
\end{tabular}

Note: Weighted least squares (WLS) with robust standard errors in brackets and weighted data (weights are sectorand time-specific number of employees). ${ }^{*}$ significant at $10 \%,{ }^{* * *}$ significant at $5 \%,{ }^{* * *}$ significant at $1 \%$. 
Table 3. Share of non-standard workers and product innovation: interaction with hightech dummy

\begin{tabular}{|c|c|c|c|c|}
\hline VARIABLES & $\begin{array}{c}(1) \\
\text { Product } \\
\text { innovation }\end{array}$ & $\begin{array}{c}(2) \\
\text { Product } \\
\text { innovation }\end{array}$ & $\begin{array}{c}(3) \\
\text { Product } \\
\text { innovation }\end{array}$ & $\begin{array}{c}(4) \\
\text { Product } \\
\text { innovation }\end{array}$ \\
\hline Share of NSW, lag & $\begin{array}{l}-0.138 * * \\
(0.0650)\end{array}$ & $\begin{array}{l}-0.131 * * \\
(0.0666)\end{array}$ & $\begin{array}{l}-0.123 * \\
(0.0668)\end{array}$ & $\begin{array}{l}-0.144 * * \\
(0.0667)\end{array}$ \\
\hline High-tech*Share of NSW, lag & $\begin{array}{c}-0.394 * * * \\
(0.0979)\end{array}$ & $\begin{array}{c}-0.408 * * * \\
(0.100)\end{array}$ & $\begin{array}{c}-0.411 * * * \\
(0.101)\end{array}$ & $\begin{array}{c}-0.427 * * * \\
(0.103)\end{array}$ \\
\hline Internal R\&D expenditure, lag & $\begin{array}{c}0.778 * * * \\
(0.207)\end{array}$ & $\begin{array}{c}0.755^{* * * *} \\
(0.204)\end{array}$ & $\begin{array}{c}0.711 * * * \\
(0.203)\end{array}$ & $\begin{array}{c}0.735 * * * \\
(0.205)\end{array}$ \\
\hline Expenditure in machinery, lag & $\begin{array}{c}0.244 \\
(0.404)\end{array}$ & $\begin{array}{c}0.243 \\
(0.397)\end{array}$ & $\begin{array}{c}0.364 \\
(0.399)\end{array}$ & $\begin{array}{c}0.530 \\
(0.406)\end{array}$ \\
\hline Size & $\begin{array}{c}5.922 * * * \\
(2.283)\end{array}$ & $\begin{array}{c}6.686^{* * * *} \\
(2.327)\end{array}$ & $\begin{array}{c}6.741 * * * \\
(2.370)\end{array}$ & $\begin{array}{l}5.182 * * \\
(2.608)\end{array}$ \\
\hline$\Delta$ Value-added, lag & & $\begin{array}{l}-0.230 \\
(0.168)\end{array}$ & $\begin{array}{l}-0.252 \\
(0.168)\end{array}$ & $\begin{array}{l}-0.274 \\
(0.174)\end{array}$ \\
\hline$\Delta$ Average labour cost, lag & & $\begin{array}{c}0.385 \\
(0.309)\end{array}$ & $\begin{array}{c}0.381 \\
(0.309)\end{array}$ & $\begin{array}{c}0.430 \\
(0.345)\end{array}$ \\
\hline$\Delta$ High-tech int. inputs, lag & & & $\begin{array}{l}0.676^{*} \\
(0.348)\end{array}$ & $\begin{array}{c}0.716 * * \\
(0.348)\end{array}$ \\
\hline Share of managers, lag & & & & $\begin{array}{c}0.0212 \\
(0.0536)\end{array}$ \\
\hline Share of manual workers, lag & & & & $\begin{array}{l}-0.0681 \\
(0.0526)\end{array}$ \\
\hline High-tech $=1$ & $\begin{array}{c}23.28 * * * \\
(2.664)\end{array}$ & $\begin{array}{c}24.19 * * * \\
(2.731)\end{array}$ & $\begin{array}{c}24.51 * * * \\
(2.762)\end{array}$ & $\begin{array}{c}22.64 * * * \\
(3.161)\end{array}$ \\
\hline Period & YES & YES & YES & YES \\
\hline Country & YES & YES & YES & YES \\
\hline Pavitt & YES & YES & YES & YES \\
\hline Constant & $\begin{array}{c}46.04 * * * \\
(2.170)\end{array}$ & $\begin{array}{c}45.68^{* * * *} \\
(2.248)\end{array}$ & $\begin{array}{c}44.18^{* * *} \\
(2.345)\end{array}$ & $\begin{array}{c}45.39 * * * \\
(3.696)\end{array}$ \\
\hline $\begin{array}{l}\text { Observations } \\
\text { R-squared }\end{array}$ & $\begin{array}{c}580 \\
0.681\end{array}$ & $\begin{array}{c}575 \\
0.684\end{array}$ & $\begin{array}{c}572 \\
0.686\end{array}$ & $\begin{array}{c}521 \\
0.693\end{array}$ \\
\hline
\end{tabular}

Note: Weighted least squares (WLS) with robust standard errors in brackets and weighted data (weights are sectorand time-specific number of employees). ${ }^{*}$ significant at $10 \%,{ }^{* *}$ significant at $5 \%,{ }^{* * *}$ significant at $1 \%$. 
Table 4. Share of non-standard workers and process innovation: interaction with hightech dummy

\begin{tabular}{|c|c|c|c|c|}
\hline VARIABLES & $\begin{array}{c}(1) \\
\text { Process } \\
\text { innovation }\end{array}$ & $\begin{array}{c}(2) \\
\text { Process } \\
\text { innovation }\end{array}$ & $\begin{array}{c}(3) \\
\text { Process } \\
\text { innovation }\end{array}$ & $\begin{array}{c}(4) \\
\text { Process } \\
\text { innovation }\end{array}$ \\
\hline Share of NSW, lag & $\begin{array}{c}-0.151 * * * \\
(0.0478)\end{array}$ & $\begin{array}{c}-0.144 * * * \\
(0.0480)\end{array}$ & $\begin{array}{c}-0.146^{* * *} \\
(0.0489)\end{array}$ & $\begin{array}{c}-0.195 * * * \\
(0.0464)\end{array}$ \\
\hline High-tech*Share of NSW, lag & $\begin{array}{l}-0.0737 \\
(0.0652)\end{array}$ & $\begin{array}{l}-0.0785 \\
(0.0667)\end{array}$ & $\begin{array}{l}-0.0768 \\
(0.0670)\end{array}$ & $\begin{array}{l}-0.0643 \\
(0.0678)\end{array}$ \\
\hline Internal $R \& D$ expenditure, lag & $\begin{array}{c}0.179 \\
(0.130)\end{array}$ & $\begin{array}{c}0.164 \\
(0.125)\end{array}$ & $\begin{array}{c}0.173 \\
(0.124)\end{array}$ & $\begin{array}{c}0.121 \\
(0.125)\end{array}$ \\
\hline Expenditure in machinery, lag & $\begin{array}{l}0.547 * \\
(0.309)\end{array}$ & $\begin{array}{l}0.544 * \\
(0.305)\end{array}$ & $\begin{array}{l}0.520 * \\
(0.309)\end{array}$ & $\begin{array}{l}0.523 * \\
(0.312)\end{array}$ \\
\hline Size & $\begin{array}{l}4.076 * \\
(2.198)\end{array}$ & $\begin{array}{c}4.773 * * \\
(2.121)\end{array}$ & $\begin{array}{c}4.768 * * \\
(2.105)\end{array}$ & $\begin{array}{c}4.308 * * \\
(2.043)\end{array}$ \\
\hline$\Delta$ Value-added, lag & & $\begin{array}{l}-0.233 * \\
(0.130)\end{array}$ & $\begin{array}{l}-0.229 * \\
(0.131)\end{array}$ & $\begin{array}{c}-0.255^{*} \\
(0.136)\end{array}$ \\
\hline$\Delta$ Average labour cost, lag & & $\begin{array}{l}0.356^{*} \\
(0.191)\end{array}$ & $\begin{array}{l}0.359 * \\
(0.192)\end{array}$ & $\begin{array}{l}0.376^{*} \\
(0.209)\end{array}$ \\
\hline$\Delta$ High-tech int. inputs, lag & & & $\begin{array}{l}-0.154 \\
(0.231)\end{array}$ & $\begin{array}{l}-0.123 \\
(0.228)\end{array}$ \\
\hline Share of managers, lag & & & & $\begin{array}{l}-0.0513 \\
(0.0437)\end{array}$ \\
\hline Share of manual workers, lag & & & & $\begin{array}{c}-0.0820 * * \\
(0.0399)\end{array}$ \\
\hline High-tech $=1$ & $\begin{array}{c}4.816^{* *} \\
(1.986)\end{array}$ & $\begin{array}{c}5.575 * * * \\
(2.017)\end{array}$ & $\begin{array}{c}5.521 * * * \\
(2.016)\end{array}$ & $\begin{array}{c}5.006 * * \\
(2.270)\end{array}$ \\
\hline Period & YES & YES & YES & YES \\
\hline Country & YES & YES & YES & YES \\
\hline Pavitt & YES & YES & YES & YES \\
\hline Constant & $\begin{array}{c}38.64 * * * \\
(1.899)\end{array}$ & $\begin{array}{c}38.51 * * * \\
(1.928)\end{array}$ & $\begin{array}{c}38.84 * * * \\
(2.048)\end{array}$ & $\begin{array}{c}43.69 * * * \\
(3.121)\end{array}$ \\
\hline Observations & 579 & 574 & 571 & 520 \\
\hline R-squared & 0.619 & 0.626 & 0.626 & 0.640 \\
\hline
\end{tabular}

Note: Weighted least squares (WLS) with robust standard errors in brackets and weighted data (weights are sectorand time-specific number of employees). ${ }^{*}$ significant at $10 \%,{ }^{* *}$ significant at $5 \%,{ }^{* * *}$ significant at $1 \%$. 


\section{Figures}

Figure 1. Evolution of the components of non-standard work, 1995-2018

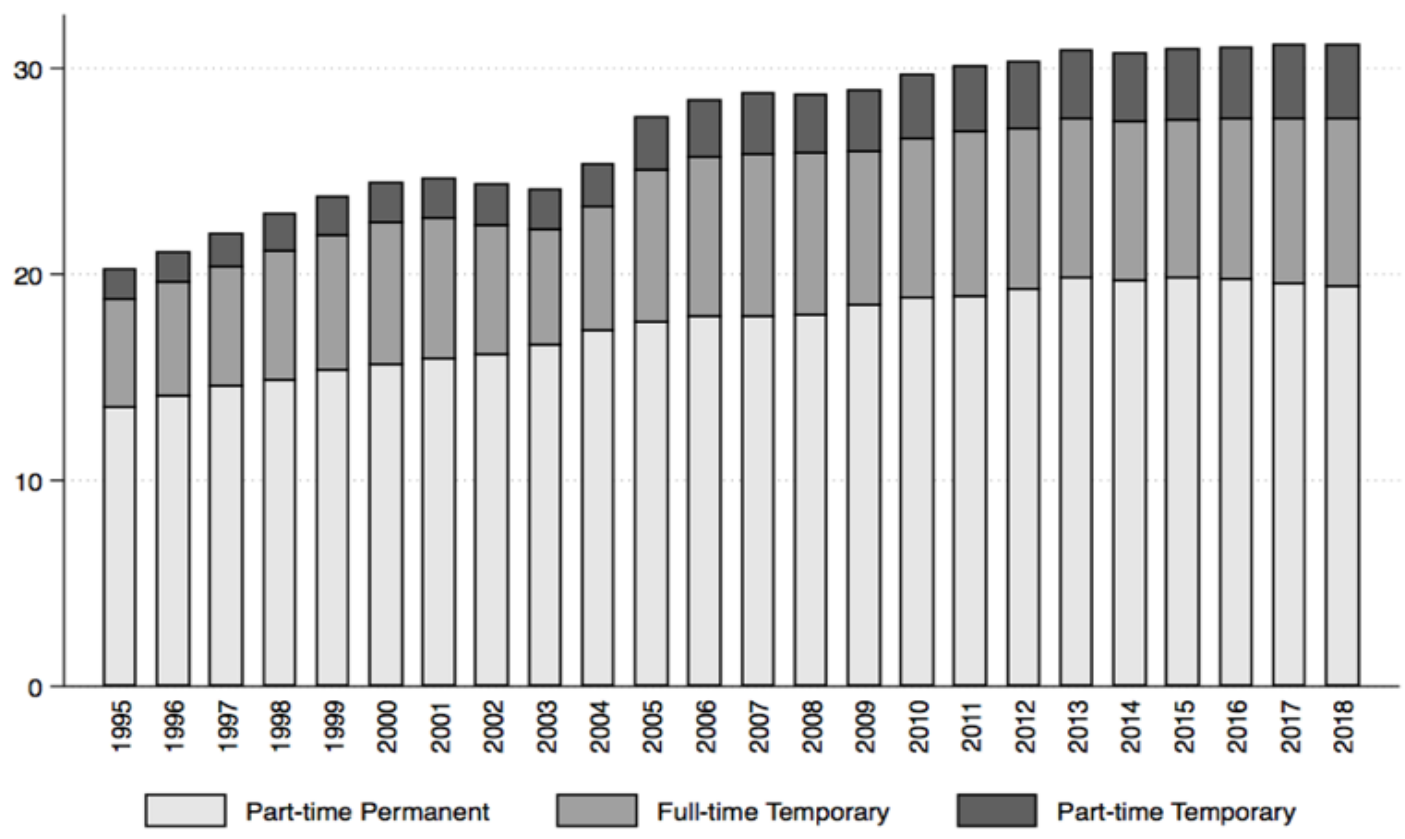

Source: authors' elaboration based on EU LFS data.

Note: countries included are DE, FR, IT, NL, UK.

Figure 2. Non-standard work by country, 1995-2018

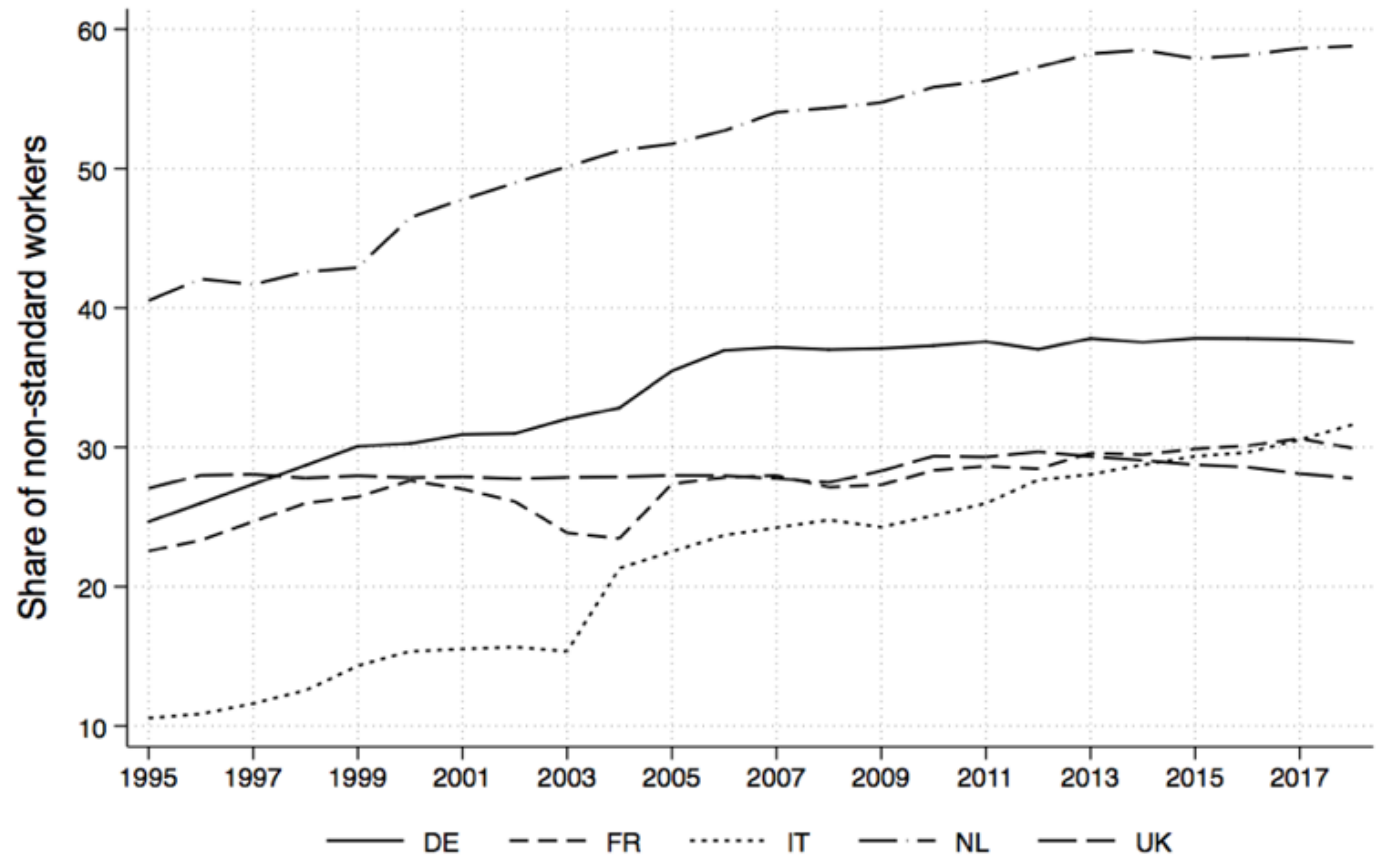

Source: authors' elaboration based on EU LFS data.

Note: countries included are DE, FR, IT, NL, UK. 
Figure 3. Innovation performance and share (\%) of non-standard workers, 1996-2016
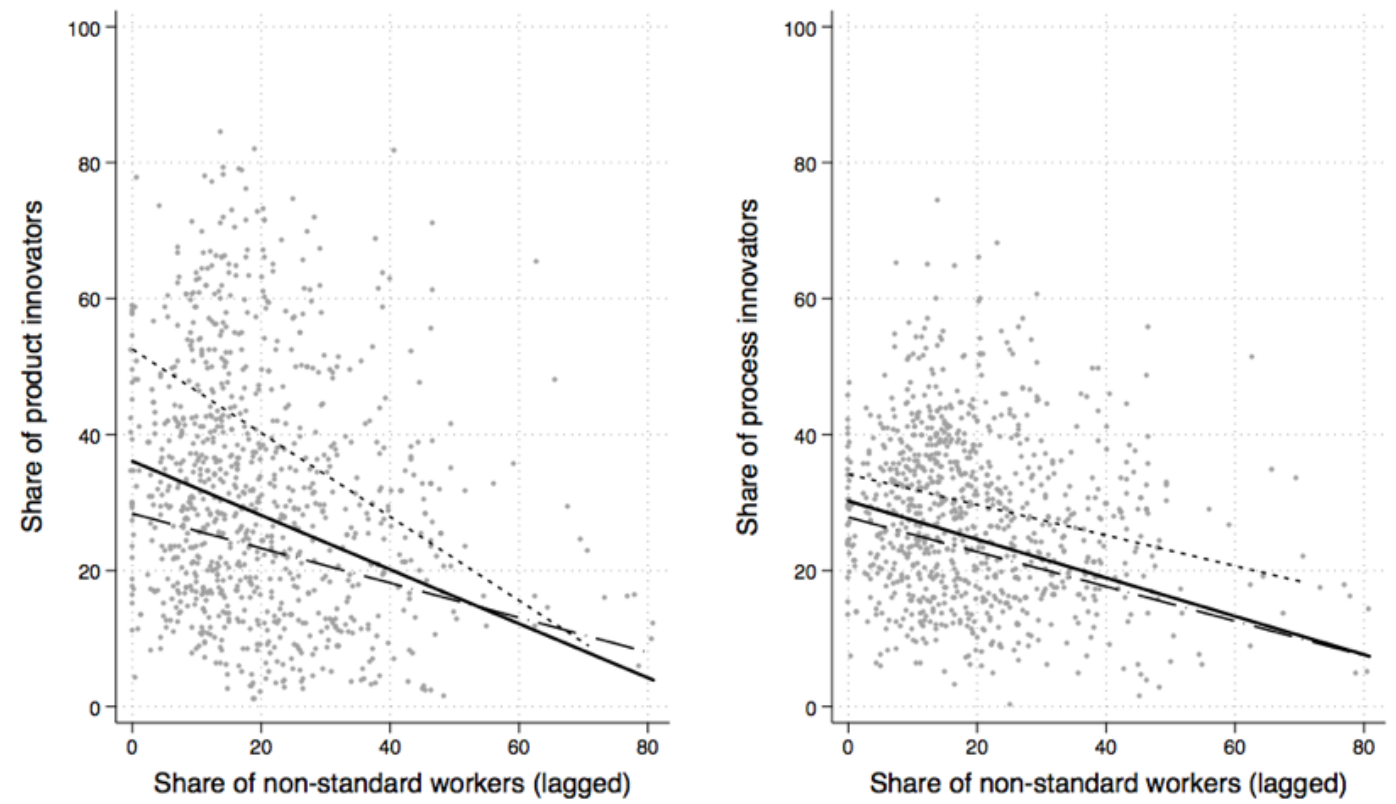

High-tech

- - Low-tech

Source: authors' elaboration on SID database.

Note: countries included are DE, FR, IT, NL, UK. 